\title{
OIL PRICES AND STOCK MARKETS: A REVIEW OF THE THEORY AND EMPIRICAL EVIDENCE
}

\author{
Stavros Degiannakis ${ }^{1,2}$, George Filis ${ }^{1,2 *}$, Vipin Arora ${ }^{3}$ \\ ${ }^{1}$ Department of Economics and Regional Development, Panteion University of Social and \\ Political Sciences, 136 Syggrou Avenue, 17671, Greece. \\ ${ }^{2}$ Department of Accounting, Finance and Economics, Bournemouth University, 89 \\ Holdenhurst Road, Executive Business Centre, BH8 8EB, Bournemouth, UK. \\ ${ }^{3}$ U.S. Energy Information Administration, 1000 Independence Ave., SW, Washington, DC \\ 20585, United States. \\ *Corresponding author: gfilis@ bournemouth.ac.uk
}

\begin{abstract}
Do oil prices and stock markets move in tandem or in opposite directions? The complex and time varying relationship between oil prices and stock markets has caught the attention of the financial press, investors, policymakers, researchers, and the general public in recent years. In light of such attention, this paper reviews research on the oil price and stock market relationship. The majority of papers we survey study the impacts of oil markets on stock markets, whereas, little research in the reverse direction exists. Our review finds that the causal effects between oil and stock markets depend heavily on whether research is performed using aggregate stock market indices, sectoral indices, or firm-level data and whether stock markets operate in net oil-importing or net oil-exporting countries. Additionally, conclusions vary depending on whether studies use symmetric or asymmetric changes in the price of oil, or whether they focus on unexpected changes in oil prices. Finally, we find that most studies show oil price volatility transmits to stock market volatility, and that including measures of stock market performance improves forecasts of oil prices and oil price volatility. Several important avenues for further research are identified.
\end{abstract}

Keywords: Oil prices, stock markets, interconnectedness, forecasting, oil-importers, oil-exporters.

JEL codes: G15, Q40, Q47 


\section{Introduction}

Oil price fluctuations over the last ten years have been remarkable. After an extremely calm twenty-year period between 1986 and 2006, Brent crude oil prices rose from $\$ 60$ to $\$ 145$ between 2007 and 2009, and then fell sharply to $\$ 30$. A few years later-in 2014 and 2015-oil prices lost nearly $75 \%$ of their value within a few months.

Such price surges, sharp declines and volatility have coincided more and more with corresponding movements in stock markets, attracting the attention of the research community, practitioners, policy makers and investors in order to assess the interconnectedness between the two markets ${ }^{1}$.

During important events related to the oil market - the price rally between 2006 and 2008, price fluctuations during the Arab Spring, or the oil price plunge of 2015 - the relationship between oil and stock markets has caught the attention of media, particularly the financial press (see, for instance, "Oil slide spurs global equity rally" (Financial Times, 2006), "How the Syrian unrest affects world markets" (The Conversation, 2013), "Oil, Stocks at Tightest Correlation in 26 Years" (Wall Street Journal, 2016) or "Oil rally propels Wall Street to record” (Reuters, 2016)).

For all its fanfare, the oil/stock market relationship does not necessarily exhibit a stable pattern over time. Figure 1 shows there are periods of coupling and decoupling between the two markets.

\section{[FIGURE 1 ABOUT HERE]}

Thus, there are some key questions that seek convincing responses. For instance, what explains the relationship between oil and stock prices? How stable is this relationship and what factors might drive structural shifts? Do all stocks respond similarly to oil prices changes? Are the links between oil and stock markets the same for oil-importing and oil-exporting economies? How important is financialization of the oil market for financial markets?

This survey provides a detailed account of the current literature as it stands in relation to answering such questions. In this study we do not simply accomplish the mapping of the literature, but we synthesise various pieces of the literature and we

\footnotetext{
${ }^{1}$ Such interest follows the well-established evidence that oil prices exercise a significant impact on economic activity. Hamilton (1983) pioneered this line of research, claiming that seven out of the eight US recessions from WWII until the early 1980's coincided with oil price surges. Hamilton (1983) also maintained that since 1973 the relationship between oil prices and economic conditions had become more systematic.
} 
draw insights that might not emerge from focusing on individual papers. We also hope to open new avenues in this interesting line of research. We begin in section 2 by reviewing the theoretical transmission mechanisms between oil and stock market performance. Section 3 focuses on the empirical relationship between oil price changes and stock market returns, whereas section 4 concentrates its attention on the effects of oil price shocks on stock market returns. Section 5 discusses the interconnectedness between the volatilities of the two markets, and section 6 analyses the role of stocks markets in forecasting oil prices and oil price volatility. Section 7 concludes the review.

A summary of the studies that are analysed in this paper can be found in the Appendix.

\section{Theoretical transmission mechanisms between oil and stock market returns}

In this section we set the scene and explain some theoretical transmission mechanisms by which oil price changes can alter the behaviour of stock markets. We categorize the channels in five different ways.

\subsection{Stock valuation channel}

The stock valuation channel is the direct channel by which oil prices influence stock markets. Making this clear requires two equations: first, we define stock returns $\left(R_{i, t}\right)$ as the first log-difference as:

$$
R_{i, t}=\log \left(P_{i, t} / P_{i, t-1}\right)
$$

where $P_{i, t}$ denotes the stock price of firm $i$ at time $t$. Second, economic theory suggests that current stock prices reflect the discounted future cash flows of a particular stock (Huang et al., 1996). This can be shown as:

$$
P_{i, t}=\sum_{n=t+1}^{N}\left(\frac{E\left(C F_{n}\right)}{(1+E(r))^{n}}\right),
$$

where $C F_{n}$ is the cash flow at time $n$ and $r$ is the discount rate. $E(\cdot)$ denotes the expectation operator.

Eqs. 1 and 2 show that stock returns are impacted by factors that can alter the expected cash flows and/or the discount rate, including oil prices. Oil price changes can alter a firm's future cash flows either positively or negatively, depending on whether the firm is an oil-user (oil-consumer) or oil-producer (see Oberndorfer, 2009; Mohanty and Nandha, 2011). For an oil-consuming firm, oil is one of the major 
production factors and consequently an increase in oil prices will result in an increase of production costs (assuming that there are no perfect substitution effects between production factors, see Basher and Sadorsky, 2006), which, in turn, will reduce profit levels and thus future cash flows (Bohi 1991; Mork, Olsen, and Mysen 1994; Hampton, 1995; Brown and Yucel 1999; Filis et al., 2011). On the other hand, for an oil-producer the oil price increase will result in increased profit margins and thus increased expected cash flows. Intuitively, we expect oil-users to exhibit bearish behaviour during periods of oil price increase, whereas the reverse holds true for oilproducing firms.

\subsection{Monetary channel}

Oil price changes also affect the expected discount rates of future cash flows (see Eq. 2). According to Mohanty and Nandha (2011), the discount rate is at least partially composed of expected inflation and expected real interest rates. Thus, the second transmission mechanism by which oil price changes impact stock returns is through inflation and interest rates.

As mentioned in section 2.1, rising oil prices result in increased production costs. However, these costs will be transferred to consumers, leading to higher retail prices and thus higher expected inflation (see Abel and Bernanke 2001; Hamilton 1996, 1988; Barro 1984, among others). Assuming that a central bank follows some type of rule ${ }^{2}$, we expect monetary policy makers to increase short-term interest rates in response to higher inflationary pressures (Basher and Sadorsky, 2006).

There are two main effects of the increased short-term interest rates on stock markets. First, increases in short-term interest rates lead to an increase in commercial borrowing rates (i.e., discount rates) for any future firm investments, raising the borrowing costs of firms. Furthermore, the increased borrowing costs lead to fewer positive NPV projects (lower cash flows). Thus, either due to increased discount rates and/or lower cash flows, stock prices decrease in value.

\footnotetext{
2 The most well-known rule is that of Taylor (1993). It is designed to approximate the response of short-tern nominal interest rates, as these are set by the central bank, when economic conditions change. The rule assumes that the monetary policy target is to stabilize the economy and price levels. More specifically, the rule "recommends" short-term nominal interest rates are influenced by the actual inflation rate, the inflation gap (i.e. the difference between the actual inflation rate and the inflation target), the output gap (i.e. the difference between the actual level of output and the output at "full employment" conditions) and expected equilibrium short-term interest rates that are consistent with a "full employment" condition. Thus, the rule suggests an increase in interest rates when inflation or output is above the target, for example.
} 
We should highlight here that the magnitude of the aforementioned effects depends on the central bank's credibility to stabilize inflation. Assuming a highly credible central bank, we maintain that inflation expectations will remain stable, despite an oil price increase, and thus close to the inflation target. Through this expectations channel, we do not expect a significant increase in inflation following an oil price increase. By contrast, in the case of a low credibility central bank, inflation expectations will be volatile and this results in a larger change of inflation expectation, following an oil price increase, leading to an even worse impact on stock price levels.

\subsection{Output channel}

The third channel is the output channel. The literature maintains that oil price fluctuations affect aggregate output (see, inter alia, Hamilton, 1983; Hamilton, 2003; Kilian, 2008a, 2008b; Hamilton, 2009a). According to this channel, positive oil price changes are expected to have both an income and a production cost effect, which will lead to changes in aggregate output. The production cost effect was explained in section 2.1, so we will concentrate on the income effect in this section.

More specifically, increased oil prices tend to lead to lower the discretionary income of households, due to the changes in retail prices (as a result of increased production costs), but also due to the increased prices of gasoline and heating oil (Bernanke, 2006; Edelstein and Kilian, 2009). Lower income leads to lower consumption and thus aggregate output, which further leads to lower labour demand. Put differently, an increase in oil prices will worsen the terms-of-trade for an oilimporting economy, which will result in lower income and a negative wealth effect on consumption, and in turn to lower aggregate demand (Svensson, 2005 and 2006). Stock markets tend to respond negatively to such developments. We maintain that this will be the response of stock markets, based on Eqs. 1 and 2. In particular, lower aggregate demand leads to lower expected cash flows for firms, which further leads to lower stock prices.

These effects are not expected to hold for all economies. On the contrary, they depend on whether an economy is oil-importing or oil-exporting. The aforementioned sequence of events holds for an oil-importing economy. On the other hand, even though an oil-exporting economy will also experience negative production cost effects, it will benefit from a positive income effect, due to increased oil revenues (the 
value of export demand for oil rises), leading to higher aggregate demand and thus higher output. The positive change in the aggregate demand will occur only if the income effect is such that it can counterbalance the negative production cost effect. In such a case, stock markets will respond favourably to the increased output, as it will boost the expected cash flows of the firms that operate in the country.

\subsection{Fiscal channel}

The fiscal channel is primarily concerned with oil-exporting economies, which are financing physical and social infrastructure using their oil revenues (see, Ayadi 2005; Farzanegan 2011; Emami and Adibpour 2012). Increased oil prices tend to lead to a transfer of wealth from oil-importing economies to oil-exporting ones (Dohner, 1981), which allow for increased government purchases. Assuming that consumption and government purchases are considered complements, then the latter will lead to higher household consumption. In such a case, private firms are expected to increase their cash flows and thus their profitability. Such developments will push stock prices to higher levels and the stock market will exhibit a bullish period.

By contrast, if consumption and government purchases are regarded as substitutes then the opposite impact will be evident, due to the crowding out effects. Stock markets will respond negatively to such developments, as the substitution effect will drive out the most productive private capital of the economy.

\subsection{Uncertainty channel}

The final transmission channel is the uncertainty channel, suggested by Brown and Yücel (2002). In particular, rising oil prices cause higher uncertainty in the real economy, due to the effects of the former on inflation, output, consumption, etc. Thus, increased oil prices will reduce firms' demand for irreversible investments, which in turn, reduce expected cash flows. Furthermore, uncertainty is also propagated to households which reduce their consumption of durable goods (Bernanke 1983; Pindyck 2003). Rising uncertainty about future oil costs increases the incentives of households to save rather than consume (Edelstein and Kilian, 2009). It is worth noting here that as uncertainty rises due to increased oil prices, the value of postponing both investment and consumption decisions increases and thus, a decrease in the incentive to invest or consume is observed, which thereby dampens economic growth prospects (Chuku et al., 2010) and thus stock market returns. 


\subsection{Combining the different channels in an aggregate framework}

Effects of the aforementioned channels are illustrated in Figures 2 and 3 using the IS-LM/AD-AS framework. These are general representations chosen to highlight the five channels - specific quantitative values ultimately depend upon the shapes of each curve. Additionally, the magnitude and timing of any effects are not obvious and depend on the responsiveness of aggregate demand and output.

Figure 2 shows the effects of a positive oil price change in an oil-importing economy.

\section{[FIGURE 2 ABOUT HERE]}

A higher oil price leads to lower disposable — due to increased heating and fuel costs - and this negative income effect pushes the AD curve to the left (from AD1 to $\mathrm{AD} 2)$. The $\mathrm{AD}$ curve shifts further to the left due to production effects, as some portion of these will be passed on to consumers via increased retail prices, lowering consumption. The AS curve also responds to the negative income effect and increased production costs, shifting left (from AS1 to AS2). These leftward shifts of the AD and AS curves lead to cost-push inflation (price levels move from P1 and P2) and lower output (from Y1 to Y2). Lower consumption and output also lead to reduced levels of employment (the labour market curve moves from FE1 to FE2).

Assuming that the monetary authority tries to counteract potential increases in inflation by reducing the supply of money (the LM curve moves from LM1 to LM2), short-run interest rates will be higher (from r1 to r2). Additionally, the effects of the oil price increase on inflation, output, consumption, etc., lead to an increase in economic uncertainty. The latter forces firms to reduce their investment activity, which can be depicted by the leftward shift of the IS curve from IS1 to IS2. Taken together, these movements lead to lower stock market performance. Figure 3 shows the effects of a positive oil price change in an oil-exporting economy.

\section{[FIGURE 3 ABOUT HERE]}

Two opposing forces exist for an oil-exporting economy in the case of an oil price increase. On the one hand, increased oil prices lead to higher production costs (production cost effect), leading the AS curve to shift to the left (from AS1 to AS2'). On the other hand, higher oil prices lead to higher disposable income and faster economic growth (income effect), and both the AD and AS curves shift to the right (to $\mathrm{AD} 2$ and AS2, respectively). The income effect is generally larger than the production effect in oil exporting economies, and thus the aggregate output level increases from 
Y1 to Y2. This also leads to positive changes in the demand for labor (FE moves from FE1 to FE2).

Shifts of the AD and AS curves, however, trigger demand-pull inflation (price levels move from P1 to P2). Assuming that the monetary authority of the oilexporting economy responds with contractionary monetary policy, this shifts the LM curve to the left (from LM1 to LM2), creating upward movement in interest rates (from r1 to r2).

There are two more effects that a positive oil price increase causes in an oilexporting economy: the possibility for higher government purchases and lower economic uncertainty. Both these effects tend to push the IS curve to the right (from IS1 to IS2). Taken together, these movements lead to higher stock market performance.

A summary of the aforementioned channels is also shown in Figure 4.

[FIGURE 4 ABOUT HERE]

\section{Relationship between oil price and stock market returns}

This section is concerned with in-depth analysis of the relationship between oil price changes and stock market returns. We investigate the empirical evidence and review the econometric methods and data used in the literature.

\subsection{Empirical evidence}

\subsubsection{Aggregate, sectoral and firm level analysis}

Hamilton (1983) was among the first to document that oil price changes regularly exercise a significant impact on economic activity in the US. Hamilton (1983) went as far as to suggest that most US recessions from the end of WWII up until 1983 were the result of energy price surges.

Interestingly enough, despite this early evidence of the effects of oil prices on economic activity, the research on the effects of oil prices on stock markets took about a decade to begin in earnest. In particular, the earliest studies in this strand of the literature are these by Brown and Otsuki (1990), Ferson and Harvey (1995) and Kaneko and Lee (1995), who examine the effects of oil, among other determinants, on stock market returns and report negative effects ${ }^{3}$. Nevertheless, it is the seminal

\footnotetext{
${ }^{3}$ The studies of Chen et al. (1986) and Hamao (1988) show that oil does not exhibit any effect on stock market returns.
} 
papers by Jones and Kaul (1996) and Huang et al. (1996) that led to increased interest in the relationship between oil and stock market returns. Jones and Kaul (1996) report that oil exerts a significantly negative impact on aggregate stock market returns, whereas Huang et al. (1996) do not offer support to these findings, claiming that the effects of oil on stock markets are non-existent.

Since then, a wealth of literature has emerged investigating the potential impact of oil price changes on aggregate stock market indices. See, for instance, Filis and Chatziantoniou (2014), Asteriou and Bashmakova (2013), Ciner (2013), Lee and Chiou (2011), Laopodis (2011), Filis (2010), Chen (2010), Miller and Ratti (2009), Driesprong et al. (2008), Nandha and Faff (2008), O’Neill et al. (2008), Park and Ratti (2008), Bachmeier (2008), Basher and Sadorsky (2006), Hammoudeh and Li (2005), Hammoudeh and Aleisa (2004), Sadorsky (2001), Papapetrou (2001), Faff and Brailsford (1999), Sadorsky (1999), among others.

The picture painted from the aforementioned studies suggests that positive oil price changes lead to negative stock market returns. For instance, Sadorsky (1999) focuses on US market and reports that positive changes in the price of oil are associated with decreased stock market returns, whereas the reverse does not hold. Even more, his findings provide evidence that the effects of oil on stock markets became more important between 1986 and 1996 - a period that saw significant oil price declines. Papapetrou (2001) reports similar findings, although the focus is on the emerging stock market of Greece. More recently, Asteriou and Bashmakova (2013) focus on emerging stock markets and find that stock market returns in the Central and Eastern European Countries (CEEC) economies respond negatively to positive innovations of oil prices.

On the other hand, there are authors who maintain that oil price changes do not impact stock returns (see, inter alia, Al Janabi et al., 2010; Jammazi and Aloui, 2010; Apergis and Miller, 2009; Cong et al., 2008; Henriques and Sadorsky, 2008). For instance, Cong et al. (2008) investigate the effects of oil prices changes on Chinese stock market returns and find that the former does not provide any predictive information on stock market returns in China. Jammazi and Aloui (2010) support the findings of Cong at al. (2008), examining the oil-stock relationship for UK, France and Japan.

All the aforementioned studies focus their attention on aggregate stock market indices when examining the oil-stock relationship. Nevertheless, the use of aggregate 
stock market indices may mask heterogeneous responses from different industrial sectors due to their different characteristics. These characteristics are related to whether industrial sectors can be classified as oil-users, oil-substitutes or non-oilrelated.

The evidence provided by the empirical literature is that there are indeed heterogeneous responses to oil price changes by different industrial sectors (see, among others, Broadstock et al., 2014; Scholtens and Yurtsever, 2012; Arouri, 2012; Broadstock et al., 2012; Ramos and Veiga, 2011; Arouri, 2011; Elyasiani et al., 2011; Mohanty et al., 2011; Narayan and Sharma, 2011; Arouri et al., 2011a; Arouri and Nguyen, 2010; Nandha and Faff, 2008; Boyer and Filion, 2007; El-Sharif et al., 2005; Hammoudeh and Li, 2005; Hammoudeh et al., 2004).

These studies provide strong evidence that the Oil \& Gas sector responds positively to oil price increases. For instance, Nandha and Faff (2008), who analyze 35 Datastream $^{\circledR}$ global industry indices, report that positive oil price changes have a positive effect on the Mining and Oil \& Gas industries. Nevertheless, El-Sharif et al. (2005) opine that this response is rather weak in the UK Oil \& Gas sector.

By contrast, authors such as Narayan and Sharma (2011) find evidence that sectors such as Supply, Manufacturing, Food, Chemical, Medical, Computer, Transportation, Real Estate and General Services respond negatively to positive oil price changes, whereas inconclusive findings are reported for the Electricity, Engineering and Financial sectors. Similarly, Hammoudeh and Li (2005) report the negative effects of oil price changes in the case of the Transportation sector. These findings are also supported by Nandha and Brooks (2009).

Along a similar vein, Elyasiani et al. (2011) show that positive oil price changes exercise a positive and direct effect on US oil-related and oil-substitute sectors (such as Coal, Electric-Gas Services, Oil \& Gas Extraction and Oil Refineries), whereas the effect is negative and indirect for oil-using sectors (such as Buildings, Chemicals, Plastic \& Rubber, Metal, Industrial Machinery, Transport Equipment and Air Transportation) and financial industries.

Concerning European stock markets, Scholtens and Yurtsever (2012) provide similar evidence. More specifically, they suggest that the impact of oil prices changes is heterogeneous for the different sectors. The authors consider 38 industrial sectors from 15 European countries and show that almost all sectors respond negatively to 
positive oil price changes, apart from the Oil \& Gas and Mining sectors, which respond positively to oil price changes.

Arouri and Nguyen (2010) support these findings considering data from 12 pan-European industrial sectors. In particular, they report a negative effect for sectors such as Food and Beverages, Health Care and Technology and a positive effect on the Financial, Oil \& Gas, Industrials, Basic Materials and Personal and Household Goods sectors. It is interesting to note though that Arouri (2011) in a subsequent study reports that only the Oil \& Gas sector exhibits a positive response to positive oil price changes, whereas a negative effect is evident for the Financials and Consumer Goods sectors.

Summarizing the evidence from the industrial sectors, we maintain that oilrelated and oil-substitute sectors are positively affected by changes in oil prices, whereas the reverse holds for oil-user and non-oil-related (or financial) sectors.

Interestingly enough, the literature has not extensively focused on the effects of oil price changes on firm-level stock returns, which would allow for an even more in-depth analysis, given that firms within the same sector may well exhibit heterogeneous responses to oil price changes. Boyer and Filion (2007) is one of the early studies in this line of research. They focus on 105 Canadian oil and gas firms and report that firms' stock returns respond positively to raising oil prices, mainly due to the oil-exporting character of Canada. Sadorsky (2008) uses data from 1483 firms of the S\&P1500 index and maintains that firm-level stock returns decline when oil prices increase, although these effects are more important for medium-sized firms, contrary to the small and large companies.

Narayan and Sharma (2011) also focus on US firm-level data. In particular, they consider 560 listed firms from 14 different sectors of the New York Stock Exchange. Their findings lend support to the previously reported evidence, i.e. that firms' response to oil price changes is heterogeneous and depends on the sector and the size of the firm. Similarly, Mohanty et al. (2013), concentrates on 54 US oil and gas companies and reach the same conclusion as Narayan and Sharma (2011).

Phan et al. (2015), on the other hand, separate their sample into oil producing and oil consuming firms. More specifically, they use data from the top-20 listed firms from 5 different US sectors (construction, air transport, truck transport, chemical manufacturing and petroleum). They conclude that increased oil price changes lead to appreciation of oil producer stock prices, whereas the reverse holds true for oil 
consumers. Additionally, Tsai (2015) uses daily data from 682 US listed firms and reports that the effects of oil prices on stock returns has changed as a result of the Global Financial Crisis (GFC) of 2007-09. More specifically, Tsai (2015) finds that before the GFC, oil prices were negatively influencing firms' stock returns. However, since the GFC the effects have become positive. Finally, Tsai (2015) suggests that these effects are size specific, similar to Narayan and Sharma (2011).

\subsubsection{Symmetric and asymmetric effects}

The financial literature also tries to identify whether oil prices exercise asymmetric effects on stock market returns (see, inter alia, Jiménez-Rodríguez, 2015; Broadstock et al., 2014; Chen, 2010; Cong et al., 2008; Park and Ratti, 2008) ${ }^{4}$. It is worth noting that these studies focus on either aggregate or sectoral stock market returns.

There are three types of asymmetric specifications that these studies are exploring, namely positive and negative oil price returns, scaled oil price increases and decreases (SOPI and SOPD) and net oil price increases (NOPI) ${ }^{5}$.

Park and Ratti (2008) uses all three asymmetric specifications and conclude that while the US stock market responds heterogeneously to positive and negative oil price changes, such evidence is not apparent for European stock markets. Recently, Broadstock et al. (2014) concentrate on positive oil price changes $\left(R_{o p}^{+}\right)$and $N O P I_{t}$. Their findings suggest that there is indeed an asymmetric effect of oil prices, given that some markets exhibit greater responses to positive changes in oil prices (e.g.

\footnotetext{
${ }^{4}$ The majority of the studies that concentrate on the asymmetric effects of oil prices focus on macroeconomic variables rather than financial variables (see, inter alia, Herrera et al., 2015; Kilian and Vigfusson, 2011; Jiménez-Rodríguez and Sánchez, 2005; Cunado and Gracia, 2005; Hamilton, 2003, 1996).

${ }_{5}$ The simplest specification is defined as $R_{o p}^{+}=\max \left(0, R_{o p}>0\right)$ and $R_{o p}^{-}=\min \left(R_{o p}<0,0\right)$, where $R_{o p}$ denotes log oil price returns, which are differentiated as either positive or negative. The second most common specification concerns scaled oil price increases and decreases $\left(S O P I_{t}\right.$ and $S O P D_{t}$, respectively), which try to capture the effects of oil price changes (either positive or negative) after a long period of stability (Lee et al., 1995). For monthly data, the $S O P I_{t}$ and $S O P D_{t}$ are estimated based on a AR(12)-GARCH(1,1) model, as follows: $R_{o p, t}=b_{0}+b_{1} R_{o p, t-1}+b_{2} R_{o p, t-2}+\cdots+b_{12} R_{o p, t-12}+e_{t}$, for $e_{t} \mid \Omega_{t-1} \sim N\left(0, \sigma_{t}^{2}\right)$, and $\sigma_{t}^{2}=\gamma_{0}+\gamma_{1} e_{t-1}^{2}+\gamma_{2} \sigma_{t-1}^{2}, S O P I_{t}=\max \left(0, \hat{e}_{t} / \sqrt{\hat{\sigma}_{t}^{2}}\right), \operatorname{SOPD}=\min \left(-\hat{e}_{t} / \sqrt{\hat{\sigma}_{t}^{2}}, 0\right)$, where $\hat{e}_{t}$ is the error term and $\hat{\sigma}_{t}^{2}$ is the conditional variance based on the information set $\Omega_{t-1}$. Finally, the third specification was developed by Hamilton (1996), who focuses on the net oil price increase $\left(N O P I_{t}\right)$, to identify whether the log oil price at month $t\left(o p_{t}\right)$ is higher compared to oil prices of the past year, such that $N O P I_{t}=\max \left(0, o p_{t}-\max \left\{o p_{t-1}, o p_{t-2}, o p_{t-3}, \ldots, o p_{t-12}\right\}\right)$.
} 
Tokyo, Korea and Taiwan). Nevertheless, they maintain that different specifications for capturing the asymmetric effects of oil prices could yield different results and, thus, authors should be very careful when choosing the asymmetric specification.

Furthermore, Jiménez-Rodríguez (2015) considers the $S O P I_{t}, S O P D_{t}$ and $N O P I_{t}$ specifications and reports that oil price increases tend to trigger negative responses in stock markets, which are of a higher magnitude compared to the positive responses of the latter when oil prices decrease. Phan et al. (2015) also confirm the asymmetric effects of oil prices for firm-level stock return data, given the heterogeneous responses of stock price returns to positive and negative oil price changes. Further evidence in favor of asymmetric effects is provided in Tsai's (2015) study, although only after the GFC period. More specifically, the results indicate that before the GFC there was no evidence of asymmetric effects. By contrast, during and after the GFC, firm-level stock returns are more reactive to negative changes in oil prices. Finally, Narayan and Gupta (2015) suggest that there is evidence of asymmetric oil price effects, given that negative changes in oil prices allow for superior prediction of stock price returns, compared to positive changes.

Nevertheless, there are studies which do not offer support to the aforementioned findings, concluding that there are no asymmetric effects of oil prices on stock returns (see, for instance, Bachmeier, 2008; Nandha and Faff, 2008).

\subsubsection{Oil-importing countries and oil-exporting countries}

The aforementioned effects of oil price changes on stock markets returns do not necessarily hold for all countries. Rather, Mohanty et al. (2011) maintains that oil price effects are different in countries that are oil-exporters, compared to these that are oil-importers. Hence, the negative relationship that was established in the previous sections does not necessarily hold for stock markets operating in oil-exporting countries.

Authors such as Wang et al. (2013), Arouri and Rault (2012), Mendoza and Vera (2010), Korhonen and Ledyaeva (2010), Bjornland (2009), Lescaroux and Mignon (2008), Park and Ratti (2008) and Bashar (2006) offer support to the hypothesis that the stock markets of oil-exporting economies tend to respond positively to oil price increases. The theoretical underpinning of this hypothesis stems for the arguments presented in section 2.3 of this report. 
By contrast, Al Janabi et al. (2010) report that oil prices do not tend to affect the stock markets of the Gulf Corporation Council countries (GCC). Thus oil prices cannot be used as predictors for GCC stock markets.

\subsubsection{Time-varying relationship}

A recent strand in this line of research acknowledges the fact that the relationship between oil and stock markets may not be stable over time. On the contrary, a time-varying relationship may prevail. Miller and Ratti (2009) are among the first to employ a quasi-time-varying framework in order to examine the relationship between oil price movements and stock market performance for the period from 1971 to 2008. More specifically, the authors claim that a negative relationship holds during the 70s and the 90s. By contrast, in the 80s the authors cannot report any significant effects of oil prices on stock returns. Finally, they find evidence that the negative effects of oil prices on stock markets are reversed into positive effects after 1999 .

The time-varying relationship between oil and stock markets is examined more formally, using multivariate GARCH models, by Awartani and Maghyereh (2013), Degiannakis et al. (2013), Antonakakis and Filis (2013), Chang et al. (2013), Broadstock et al. (2012), Sadorsky (2012), Filis et al. (2011), Choi and Hammoudeh (2010), and Bharn and Nikolova (2010) among others. These studies corroborate that the relationship between oil prices and stock market is time-varying and mainly driven by economic or geopolitical developments. Thus, there are periods when the two markets exhibit a positive relationship, whereas in other periods a negative relationship prevails.

For instance Filis et al. (2011) focus on both oil importing and oil exporting countries, and show that during geopolitical events (i.e. unrest in the Middle East) the relationship between oil price changes and stock returns is negative, whereas during recessions or economic booms the relationship turns positive. Even more, the authors do not find any significant relationships between oil exporting and oil importing stock markets. Similarly, Broadstock et al. (2012) concentrate on China and report a sharp increase in the correlation between oil and stock returns since the GFC. A different approach is undertaken by Antonakakis and Filis (2013), who examine the timevarying effects of oil prices changes on the dynamic correlation between stock markets. They show that oil price changes affect the time-varying stock market 
correlations among oil-importing countries, whereas no effects are reported for the correlations among oil-exporting countries.

Furthermore, Degiannakis et al. (2013) confirm the aforementioned timevarying relationship for all industrial sectors, regardless of whether these are oil-users, oil-related, oil-substitutes and non-oil-related. Sadorsky (2012) focuses only on the technology and energy sector. He reports that the time-varying correlation between these two sectors and oil price changes fluctuates in both positive and negative regions for both sectors. This is a rather important finding given that the studies reviewed in section 3.1.1 advocate in favour of a positive effect of oil price changes on the energy sector.

Finally, Awartani and Maghyereh (2013) show that the effects between oil and stock markets are time-varying and bidirectional. However, it is evident that the oil market exercises greater effects on stock markets rather than the reverse. In addition, they show that these bidirectional effects are more prominent after the GFC of 200709.

A recent study that is quite distinct from the above is conducted by Broadstock and Filis (2017). The authors reconcile previous research efforts in a novel dynamic model averaging framework, at firm-level data, which allows the examination of the time-varying probability that oil shocks $\left(S O P_{t}, S O P I_{t}, S O P D_{t}\right)$ determine excess stock returns in the US. More specifically the authors employ a time-varying multifactor asset pricing framework, which includes symmetric and asymmetric oil shocks, as well as, the standard variables of the Fama and French (1993) three-factor model. Their findings convincingly suggest that oil shocks (symmetric or asymmetric) are not a 'frequent' determinant of the US excess stock returns, at least at firm-level, which is in contrast to the conventional wisdom.

\subsection{Econometric methods and data used}

In terms of econometric methods and data, these vary depending on whether the authors consider aggregate and sectoral stock market indices or firm-level data. Furthermore, the choice of econometric framework depends on the hypothesis that is examined.

More specifically, authors who concentrate on aggregate and sectoral stock market indices are primarily using monthly data and Vector Autoregressive (VAR) models, where apart from the oil price changes and stock returns, they also consider 
other macroeconomic variables, such as industrial production, interest rates, unemployment, etc. (see, for instance, Filis and Chatziantoniou, 2014; Scholtens and Yurtsever, 2012; Park and Ratti, 2008; Papapetrou, 2001; Sadorsky, 1999). The second most common model that is employed for the identification of oil price effects on stock market performance is a GARCH $(1,1)$; see, inter alia, Broadstock et al., (2014), Elyasiani et al. (2011) and Arouri and Nguyen (2010).

By contrast, authors who consider firm-level data primarily use daily data. In these studies the most common approaches are the Capital Asset Pricing Model (CAPM) or the Fama and French (1993) 3-factor model, which are augmented to incorporate oil price changes (see, Phan et al., 2015; Mohanty et al., 2013; Narayan and Sharma, 2011, among other).

The use of real and nominal oil and stock market data vary among the different authors. In any case we do not find heterogeneous results depending on the use of real or nominal data.

This also applies for studies which examine either the asymmetric effects of oil prices or the effects of oil prices for oil-exporting and oil-importing economies.

On the other hand, studies that investigate the time-varying relationship between oil and stock markets (either for aggregate stock market or sectoral indices) use monthly data and employ multivariate GARCH models, such as the Dynamic Conditional Correlation by Engle (2002) or the BEKK model of Baba et al. (1991) and Engle and Kroner (1995). See, for example, Degiannakis et al. (2013) Broadstock et al. (2012), Filis et al. (2011), Choi and Hammoudeh (2010).

\section{Relationship between oil price shocks and stock market returns}

Having examined the relationship between oil price changes and stock markets, we proceed with the investigation of oil price shocks and stock market performance. The section starts with the definitions of oil price shocks and continues with an in-depth review of empirical findings. It then proceeds with the review of econometric methods and data employed in the financial literature.

\subsection{Defining oil price shocks}

The studies that have been reviewed in this report so far have used changes in oil prices, measured by the first log-difference, when assessing the oil-stock market relationship. Furthermore, some other studies have referred to oil price shocks (a la 
Lee et al., 1995, i.e. SOPI and SOPD), although this was used for the identification of asymmetric oil price effects. However, since Barsky and Kilian (2002, 2004) and subsequently by Kilian (2008b, 2009) and Hamilton (2009a, 2009b), the notion of oil price shock has received a completely different understanding.

In particular, oil price shocks are identified based on the sources that cause oil prices to change. The emergence of these shocks is important in understanding better the relationship between oil and stock market performance. Thus, before we investigate this aforementioned relationship, we must first define an oil price shock, according to the aforementioned authors. In short, an oil price shock reflects a change in the price of oil due to an unanticipated change in oil market fundamentals (i.e. global supply or demand of oil).

Kilian $(2008 b, 2009)$ maintain that there are three types of oil price shocks, namely, the supply-side, aggregate demand and precautionary demand shocks. According to these studies supply-side shocks are related to restrictions in oil supply by OPEC, via cartel behavior, as a strategy to inflate oil prices. On the other hand, geopolitical unrest, primarily observed in the Middle-East region, does not lead to supply-side oil price shocks. On the contrary, they posit that these events trigger precautionary demand shocks, which result due to the uncertainty that the geopolitical turbulence imposes on economic agents about the future availability of oil. To put it simply, Kilian and co-authors maintain that economic agents expect a shortage in oil supply soon after initiation of geopolitical unrest and, thus, they increase their demand for oil instantly, driving oil prices to higher levels.

The aggregate demand shocks, according to Kilian's studies are related to oil price changes which are influenced by movements in the global business cycle. For instance, the remarkable growth of the Chinese and other emerging economies from 2004 to 2007 significantly increased oil demand from these countries, while oil supply did not follow suit, driving oil prices to unprecedented levels. Equivalently, the global economic recession during the Global Financial Crisis of 2007-09 led to the collapse of oil prices, as the dramatic reduction of oil demand was not accompanied by a reduction in the supply of oil.

Hamilton (2009a, 2009b) maintains that oil prices change in response to either geopolitical or economic events, which suggests that oil prices change due to supply disruptions (supply-side shocks) or economic growth/downturns (demand-side shocks). Hamilton adopts a similar interpretation for his demand-side shocks, as in the 
case of Kilian. Nevertheless, unlike Kilian's evidence, Hamilton suggests that supplyside shocks are driven by events such as the Yom Kippur War in 1973, the Iranian revolution in 1978, Iraq's invasion of Iran and Kuwait in 1980 and 1990, respectively, the Arab Spring in 2010 or Syrian unrest in 2011. Such shocks lead to major oil production disruptions, which are not accommodated by a similar reduction in the demand for oil and thus drive oil prices to higher levels.

Overall, the argument behind the development of oil price shocks as a mechanism to explain the effects of the oil market on stock market performance stems from the fact that oil price changes are not necessarily exogenous, as it was the common approach of previous studies. On the contrary, reverse causality, between macro-finance variables and oil prices, does exist and, hence, not all oil price movements are exogenous, but they could be influenced by the wider economic activity, as was first shown by Barsky and Kilian (2002). This line of research was delayed primarily due to the unavailability of data that would be able to capture the dynamics of the industrial commodities demand, as these are influenced by the global business cycle (Kilian, 2009).

\subsection{Empirical evidence}

\subsubsection{Aggregate, sectoral and firm level analysis}

Kilian and Park (2009) utilize Kilian's (2009) definitions of oil price shocks for the US stock market, and show that the different oil price shocks trigger different responses from the stock market. In particular, they find that stock market returns do not really respond to supply-side shocks, whereas positive (negative) responses are observed during aggregate demand (precautionary demand) shocks. In other words, stock markets do not seem to react to OPEC decisions to restrict oil supply in order to generate increases in the price of oil. Such findings might be justified by the fact that OPEC decisions are somewhat anticipated and, thus, they are discounted by market participants. By contrast, positive aggregate demand shocks seem to be regarded as positive news for stock markets (hence the positive response), even though they create an upward movement in oil prices. This is expected, as positive aggregate demand shocks reflect periods of economic growth, which are positive news for financial markets. Finally, the negative responses of the stock markets to positive precautionary demand shocks suggest that uncertainty in the oil market, which is 
created due to geopolitical unrest and associated anticipated future shortfalls in oil supply, is transmitted to financial markets.

Kilian and Park (2009) also provide evidence that the effects of oil price shocks are industry-specific. In particular, they show that the Automobile \& Trucks and Retail industries only respond (negatively) to precautionary demand shocks, whereas Petroleum \& Natural Gas and Precious Metals only respond (positively) to aggregate demand shocks.

Since Kilian and Park (2009), an increasing number of studies have examined the effects of the different oil price shocks on stock market returns and volatility (see, inter alia, Kang et al., 2017; Angelidis et al., 2015; Kang et al. 2015a; Fung and You, 2014; Gupta and Modise, 2013; Antonakakis et al., 2013; Abhyankar et al., 2013; Degiannakis et al., 2014; Kang and Ratti, 2013; Baumeister and Peersman, 2013; Basher et al., 2012).

For instance, Basher et al. (2012) use the MSCI emerging stock market index as a proxy of emerging stock market performance. They find that emerging stock markets do not seem to react to supply-side shocks, whereas a positive response is observed for both aggregate demand and precautionary demand shocks. The latter observation deviates from Kilian and Park (2009), who maintain that the precautionary demand shocks lead to lower stock market returns, given the uncertainty that they are associated with. However, a plausible explanation of this contradictory finding is the fact that the MSCI emerging stock market index comprises both oil-importing and oil-exporting economies (as we will explain in section 4.2.2, the oil price shocks effects could be different for the two types of countries). Another plausible explanation could be the fact that both India and China are included in the index. These two countries are heavy oil importers, which demand large oil quantities, regardless of its price, in order to sustain economic activity. Hence, their stock markets might be more resilient to increases in oil prices even if these are taking place due to geopolitical uncertainty.

Along a similar vein, Gupta and Modise (2013) concentrate on South Africa and their findings support those of Kilian and Park (2009) as far as the aggregate demand and precautionary demand shocks are concerned. However, they also find that negative supply-side shocks exercise a negative impact on stock market returns, suggesting that for South Africa restrictions in the supply of oil are not fully 
anticipated by the market. In addition, Abhyankar et al. (2013), focusing on the Japanese stock market, offer support to Kilian's and Park (2009) findings.

Angelidis et al. (2015) adopt a slightly different approach compared to the rest of the literature. In particular, they use Kilian's (2009) framework to extract the three oil price shocks and then they examine whether these shocks provide predictive information on stock market regimes (i.e. low and high risk periods) for the US market. The authors focus on both US stock market returns and volatility and their findings reveal that, indeed, disentangling oil price changes according to the individual shocks provides significantly incremental predictive information for the regime of US stock returns and volatility. In particular, they show that positive supply-side and aggregate demand shocks push the US market into bull territory (i.e. positive returns), whereas the precautionary demand shocks do not seem to matter. Interestingly, they document that the precautionary demand shock leads to the high volatility regime, whereas the supply-side and aggregate demand shocks do not exercise any significant effect. This is an interesting finding which suggests that stock returns and volatility respond differently to the different oil price shocks.

Kang et al. (2015a) chose to focus on the effects of oil price shocks on the covariates of US stock market returns and volatility. Their findings show that supplyside shocks do not exercise any effects, whereas negative responses are observed for the two demand-side shocks. In particular, positive aggregate demand and precautionary demand shocks lead to lower covariability between the returns and volatility of the US market.

Finally, Kang et al. (2017) investigate the effects of oil price shocks on both US aggregate oil and gas stock returns and for select oil and gas companies (i.e., Royal Dutch Shell, Exxon Mobil, BP and Chevron Corporation). Their findings for the aggregate industry's returns corroborate those of the previous studies. Additionally, they also show that even negative supply-side shocks trigger negative responses from the oil and gas sector's returns. Concerning the individual oil and gas companies, we notice that the effects are not company specific but they are industryspecific, as all shocks trigger positive responses from firm-level stock returns of the chosen oil and gas companies. The authors extend their findings in order to consider the effects of oil shocks on the upstream, midstream and downstream oil and gas companies, using one representative firm from each sector (ConocoPhillips, TransCanada Corporation and Valero Energy Corporation, respectively). They find 
that even though the responses of the latter firms are similar to the major oil and gas companies explained previously for the two demand-side shocks, ConocoPhillips, TransCanada Corporation and Valero Energy Corporation also react (negatively) to negative supply-side shocks.

Finally, there are studies that investigate the effects of the three oil price shocks on stock market volatility. Degiannakis et al. (2014), who focus on the European stock market, show evidence that stock market volatility responds negatively (i.e. reduces) to positive aggregate demand shocks, whereas no significant response is evident to supply-side and precautionary demand shocks. Their findings hold true for aggregate stock market indices, as well as for ten industrial sectors.

Kang et al. (2015a), on the other hand, concentrate on the US market and find that both demand-side shocks (i.e. aggregate demand and precautionary demand shocks) lead to lower stock market volatility.

\subsubsection{Oil-importing countries and oil-exporting countries}

Turning to studies that focus on oil-importing and oil-exporting stock markets, Apergis and Miller (2009) assess the impact of Kilian's (2009) oil price shocks on eight stock markets around the world (i.e. Australia, Canada, France, Germany, Italy, Japan, the United Kingdom, and the United States). The authors report similar findings with Kilian and Park (2009), nevertheless, they maintain that these effects are small in magnitude and, thus, they conclude that international financial markets do not really value oil shocks.

On the other hand, Jung and Park (2011) focus on Norway and Korea and document the heterogeneous responses of stock market returns and volatility to the different oil price shocks. In particular, they report that supply-side oil price shocks are not valued by stock markets, since the former does not seem to exercise any effects on the latter. Nevertheless, they report heterogeneous responses to the two demand side shocks (i.e. aggregate demand and precautionary demand shocks), which stem from the fact that Norway is an oil-exporter, whereas Korea is an oilimporting country. In particular, even though they find that the aggregate demand shocks exercise a positive effect on both the Norwegian and Korean stock markets, the effects are more prevalent for the Norwegian stock market, given the oilimporting character of the country. A clear difference in findings exists for the effects of the precautionary demand shocks. Interestingly, the latter shocks exercise a 
positive effect on Norwegian stock markets (although only in the short-run), whereas the opposite effect holds true for the Korean market.

As far as volatility is concerned, Jung and Park (2011) show that the responses are different between the two countries and among the three shocks. More specifically, they maintain that Norwegian stock market volatility responds favorably (i.e. reduces) to positive aggregate demand shocks, whereas insignificant effects are reported to supply-side and precautionary demand shocks. By contrast, it is only the precautionary demand shocks that lead to higher volatility in the case of the Korean stock market.

Furthermore, Wang et al. (2013) examine 16 stock markets (9 oil-importing and 7 oil-exporting) and find that, with the exception of Italy, none of the stock markets respond to supply-side oil price shocks; a finding which is in line with the previous literature. Furthermore, contrary to Jung and Park (2011), the authors do not find evidence of a positive response from oil-importing stock markets to positive aggregate demand shocks. The latter finding is similar to the conclusions of Apergis and Miller (2009). Nevertheless, their findings suggest that oil-exporting stock markets tend to respond positively to positive aggregate demand shocks. Finally, the results are inconclusive for precautionary demand shocks, given that for the majority of stock markets, the effects are insignificant. However, for four out of the seven oilexporting stock markets (Canada, Saudi Arabia, Norway and Russia) the positive precautionary demand shocks trigger positive responses.

Overall, we observe that the literature (although scarce) points to the fact that stock market responses are heterogeneous to the different oil shocks, and also country-specific, depending on whether the country is an oil-importer or oil-exporter. These findings are justified by the fact that even though aggregate demand shocks are regarded as positive news, they also push production costs to higher levels for oilimporting economies, whereas higher oil prices provide greater incentives for investment and consumption in the oil-exporting country. Hence, aggregate demand shocks are more profound for the stock markets of oil exporters. Regarding the difference in stock market responses to precautionary demand shocks, this stems from the fact that even though such shocks are related to geopolitical tensions, the oilexporting economy can have some short-term benefits from the increase in the price of oil. 


\subsubsection{Time-varying relationship}

There is a recent strand of the literature which suggests that the aforementioned results may be time-varying. One of the early findings in this line of research is by Filis et al. (2011), who show that the correlation between oil and stock markets is time-varying and responds to the various oil price shocks. In particular, they show that precautionary demand (aggregate demand) shocks lead to lower (higher) correlations between oil and stock market returns and though the magnitude of these correlations is not always the same, suggesting that there is an element of event-specific effects. Supply-side events do not seem to trigger changes in the correlation. The results remain qualitatively similar for both oil-importing and oilexporting economies.

A similar study is conducted by Degiannakis et al. (2013), who investigate ten European industrial sectors. They find that both the origin of the oil price shock as well as the type of the industry influence the time-varying correlation between oil and sectoral stock returns.

Broadstock and Filis (2014) employ a two-step procedure to investigate the time-varying relationship between oil price shocks and stock market returns for the US and China. They first extract the three oil price shocks using Kilian's (2009) framework, and then use the three shocks to assess whether their relationship with stock market returns is time-varying. This is the first study to explicitly show that the relationship between each of the three shocks and stock markets returns is indeed time-varying, and fluctuates between both positive and negative correlations. The only exemption is the correlation between the US stock returns and aggregate demand shocks, which always exhibit a positive correlation. The authors also proceed with the same analysis for select industrial sectors. Their evidence reveals that the relationships are time-varying and industry specific. The study also finds that the Chinese stock market seems to be more resilient to oil price shocks.

Finally, Kang et al. (2015b) employ a Time-Varying Parameter VAR model to investigate the time-varying effects of oil price shocks on US stock market returns. They show that in almost the whole study period (1973-2012) the aggregate demand (precautionary demand) shocks exercise a positive (negative) effect, although the magnitude of the effects diminish towards the latter part of the study. The supply-side shocks seem to have a significant negative effect in the early years (1973-1980), whereas marginal or insignificant effects are observed thereafter. Finally, the largest 
effect on stock market returns is observed from the aggregate demand shocks during the GFC.

\subsection{Econometric methods and data used}

All the aforementioned studies primarily use Kilian's (2009) Structural Vector Autoregressive (SVAR) model, which allows the identification of the three oil price shocks. The SVAR model uses three variables, namely global oil production, a global total spending variable (approximating aggregate demand) and US refiner's acquisition cost of crude oil (as a proxy for real oil prices).

More specifically, the global oil production variable is used to estimate the unexpected changes in oil production, which lead to supply-side oil price shocks.

Kilian's global real economic activity index is the typical global aggregate demand proxy that the aforementioned studies use. The index is estimated using data from the dry cargo freight rates for bulk dry cargoes, which consist of coal, fertilizers, grain, oilseeds, iron ore and scrap metal. The index does not measure global output, but rather is a measure for global industrial commodities demand, as a result of worldwide economic activity (i.e. the global business cycle). The justification that Kilian (2009) puts forward is rather simple and quite convincing. Increasing freight rates suggests that the shipping industry operates closer to full capacity and this is true only during times of economic booms. By contrasts, during economic recessions, the demand for shipping reduces, which further leads to a reduction in the freight rates. To put it simply, increasing (decreasing) freight rates may indicate higher (lower) global demand. This index is utilized to capture the aggregate demand oil price shocks.

Finally, according to Kilian (2009), innovations to real oil prices that are not explained by either supply-side or aggregate demand oil price shocks should reflect changes in the demand for oil for reasons other than demand for industrial commodities or production changes by OPEC. Kilian (2009) suggests that the most plausible explanation is that these innovations can be explained by changes in the precautionary demand for oil and, thus, these are named precautionary demand shocks (also named as the oil-specific demand shocks or the idiosyncratic oil demand shocks).

Furthermore, studies that examine the time-varying relationship between oil shocks and stock market performance use either multivariate GARCH models (such 
as the Dynamic Conditional Correlation of Engle (2002) or BEKK by Baba et al. (1991) and Engle and Kroner (1995)) or the Time-Varying Parameter VAR model of Primiceri (2005).

\section{Relationship between oil price volatility and stock market volatility}

In this section we turn our attention to the relationship between the volatilities of oil and stock markets. Ross (1989) maintains that volatilities from different assets can affect each other. Furthermore, Huang et al. (1996) opine that oil and stock market linkages could potentially be realized through their volatilities. Despite this prima facie evidence, only recently have researchers looked into the relationship between oil and stock market volatility (see for instance, Malik and Hammoudeh, 2007; Malik and Ewing, 2009).

This section begins by reviewing studies that focus on the static relationship between volatilities of the two markets (at either aggregate or disaggregate levels), and then proceeds to examine the relationship for oil-importing and oil-exporting countries. Next, we concentrate on their time-varying relationship, before discussing the various methodologies and data used in the empirical literature.

\subsection{Empirical evidence based on static approaches}

\subsubsection{Relationship between oil and stock market volatility}

Malik and Ewing (2009) conduct one of the early studies in this line of research. The authors concentrate on six US sectoral stock market indices, namely Financials, Industrials, Consumer Services, Health Care and Technology, and examine the relationship between sector index volatilities and crude oil price volatility. Their findings suggest heterogeneous responses from the different sectoral indices; overall they report that oil price volatility positively affects sectoral stock market volatility. Nevertheless, no evidence of such effects is reported for Financial and Industrial sectors' volatilities.

Arouri et al. (2011a) also focus on several US and European industrial sectors (i.e. Automobile \& Parts, Financials, Industrials, Basic Materials, Technology, Telecommunications and Utilities) for the period 1989-2009. Interestingly enough, the results are different not only among the different sectors (as already documented by Malik and Ewing, 2009), but also between the two financial markets. In particular, for European stock market volatility, the authors show that neither oil price volatility 
nor stock market volatility exercise any significant effects on one another. By contrast, oil volatility significantly impacts the industrial sector volatilities of Automobile \& Parts, Basic Materials and Utilities sectors in the US, whereas no effects are reported for other sectors. On the other hand, none of the industrial sector volatilities seem to impact oil price volatility. In a subsequent study, Arouri et al. (2012) corroborate the findings of Arouri et al. (2011a).

So far, studies that focus on disaggregate indices show that oil market volatility exercises a significant impact at the sectoral level. Turning to studies that utilize aggregate stock market indices, Vo (2011) investigates the inter-dependence between S\&P500 index and WTI crude oil price volatilities for the period 1999-2008. Contrary to previous evidence, the author finds a mutual inter-dependence between the two market volatilities. Similar results are also reported by Mensi et al. (2013), who examine the volatility linkages between stock and oil prices for both WTI and Brent crude oil prices. Mensi et al. (2013) find positive bidirectional effects between S\&P500 and WTI volatilities, as in the case of Vo (2011). However, these results do not hold for the Brent volatility. More specifically, the findings suggest that it is the S\&P500 volatility that exercises a significant effect on Brent crude oil volatility, rather than the reverse.

More recently, Ewing and Malik (2016) also support the findings of Vo (2011) and Mensi et al. (2013), focusing on WTI and S\&P500 volatilities, for the period 1996-2013. It is evident from the study's results that there are significant cross-market volatility effects. Nevertheless, they also report that the oil price volatility receives stronger effects from the stock market volatility, as compared with the reverse. Furthermore, Phan et al. (2016) use volatilities from the futures contracts of the S\&P500, NASDAQ and WTI and show that even in the futures markets, there are significant cross-market volatility effects.

A different approach is employed by Angelidis et al. (2015), who examine (among others) the impact of Brent crude oil volatility on the probability of the Dow Jones volatility being in a high risk regime. The authors cannot offer any support for the idea that oil price volatility exercises significant effects on stock market volatility.

\subsubsection{Oil-importing countries and oil-exporting countries}

Malik and Hammoudeh (2007) use data from 1994 to 2001 for the stock markets of the GCC region and WTI crude oil prices. Their findings show that GCC 
stock market volatilities are affected by oil price volatility, whereas the reverse does not hold true. The only exception is Saudi Arabia's stock market volatility, which is the only financial market volatility that exercises a significant effect on oil market volatility. According to the authors, such findings highlight the importance of Saudi Arabia in the global oil market.

Khalfaoui et al. (2015) use data for the stock market volatilities of the G7 countries, as well as, WTI crude oil price volatility. Even though the findings show interdependence between stock and oil volatilities, there is evidence to suggest that oil market volatility is leading stock market volatility. The authors are unable to find any heterogeneous effects between Canada (a major oil-exporting country) and the other G7 countries in the sample (oil-importers).

\subsection{Time-varying relationship between oil and stock market volatility}

Thus far, the evidence reported in the previous sections does not capture possible heterogeneous relationships between oil price and stock market volatilities over different time periods. Hence, recent studies focus on the time-varying effects of relationships between volatilities of the two markets.

Arouri et al. (2011b) reveal that the relationship between the two volatilities is indeed time-varying for GCC countries. More specifically, the oil market volatility significantly increases stock market volatility, and these effects are even more pronounced during the crisis period. Similarly, stock market volatility positively affects oil price volatility, although these effects disappear during tranquil periods. Awartani and Maghyereh (2013) provide support to the findings by Arouri et al. (2011b), as they also focus on the same stock markets and show that oil market volatility is the main transmitter of volatility shocks to stocks markets, rather than the reverse. These spillover effects are more apparent during the financial crisis.

Other studies that also concentrate on oil-exporting and oil-importing countries are those by Boldanov et al. (2016) and Maghyereh et al. (2016). Maghyereh et al. (2016) use a sample of 11 countries (3 oil-exporters and 8 oilimporters) for the period 2008-2015, and find evidence that oil price volatility is the main transmitter of volatility shocks to stock market volatilities, a finding similar to Awartani and Maghyereh (2013). The authors also do not report any distinction between oil-importing and oil-exporting countries. 
By contrast, Boldanov et al. (2016) do report heterogeneous relationships between the oil and stock market volatilities of oil-importing and oil-exporting countries. In particular, even though the relationship between the two market volatilities is positive in the case of oil-importing countries, this does not hold for the oil-exporting countries. It is evident that during geopolitical unrest and natural disasters, the relationship between oil and stock market volatilities of oil-exporters turns negative. Furthermore, the authors show that this relationship intensifies during periods of economic turbulence.

We finalize this section with two studies that focus solely on oil-importing economies. Du and He (2015) study the US market and show that there are significant risk spillovers between oil and stock markets. Disentangling the results further, they report that in the pre-financial crisis period these risk spillovers are positive and run from stock market volatilities to oil market volatilities. In parallel, there are also negative spillovers flowing from oil volatility to stock market volatility. Interestingly enough, these spillover effects change in the post-financial crisis period, where bidirectional positive spillover effects are reported. Bouri (2015), on the other hand, investigates four MENA countries (Lebanon, Jordan, Tunisia and Morocco) for the period 2003-2013. Overall, the findings reveal that there are not significant linkages between oil volatility and the volatilities of these MENA stock markets. This particularly holds for the pre-financial crisis period. Some evidence of significant linkages is reported in the post-financial crisis period, yet not for all countries. More specifically, bidirectional causality is evident between Jordanian stock market volatility and oil market volatility, whereas unidirectional causality running from oil volatility to Tunisian stock market volatility is also uncovered.

\subsection{Econometric methods and data used}

It is evident from the aforementioned studies that several different methods have been employed, as well as different sets of data. More specifically, studies use both Brent and WTI crude oil prices, although the latter is more commonly employed. In terms of stock market data, the existing literature primarily uses aggregate stock markets for the US and GCC countries. Nevertheless, G7 countries and aggregate European stock market indices have been also considered. Finally, a small number of studies consider sectoral indices, but only for the US and Europe. 
As far as data frequency is concerned, the majority of studies prefer the use of daily data, although there is a single study that has used intraday data (Phan et al., 2016). Finally, the volatility measure that is most commonly used in the studies is conditional volatility, rather than the realized volatility. There is only one study that has considered implied volatility indices (Maghyereh et al., 2016).

Turning our attention to the methods that have been used, the majority of the studies have employed a GARCH-type model, either in static frameworks (e.g. VARGARCH) or in time-varying frameworks (e.g. GARCH-BEKK, GARCH-VECH, Diagonal BEKK). However, studies which consider the time-varying relationship between the two market volatilities also consider the newly developed Spillover Index and Connectedness Index by Diebold and Yilmaz (2012 and 2014).

\section{Impact of stock markets on forecasting oil prices and oil price volatility}

Recent evidence suggests that the oil market has experienced increased financialization, especially since the start of the 2000s (see, inter alia, Büyüksahin and Robe, 2014; Silvennoinen and Thorp, 2013; Fattouh et al., 2012). The term financialization stands for increased links between the oil and stocks markets.

The wealth of literature on oil price and oil price volatility forecasting does not use the information extracted from stock markets to examine whether it can provide incremental forecasting accuracy. Instead, studies rely mainly on oil market fundamentals like global oil production, global demand and global oil inventories ${ }^{6}$, or the futures price of oil $^{7}$ when forecasting oil prices (the review of these studies falls outside the scope of this survey). ${ }^{8}$ On the other hand, the literature on oil price volatility forecasting primarily uses past information about oil price volatility to forecast future volatility ${ }^{9}$.

\subsection{Oil price forecasting}

There are only three studies that examine the informational content of stock markets when forecasting oil prices. Chen (2014) uses the US AMEX Oil Index, the

\footnotetext{
${ }^{6}$ See, for instance, Baumeister and Kilian, (2015, 2014), Baumeister et al. (2014), Manescu and Van Robays (2014), Baumeister and Kilian (2012).

${ }^{7}$ E.g. Alquist and Kilian, (2010), Murat and Tokat (2009), Coppola (2008), Knetsch (2007).

${ }^{8}$ Zagalia (2010) maintains that the forecasting of oil prices may be biased when the impact of financial markets is ignored.

${ }^{9}$ See, for example, Prokopczuk et al. (2015), Sevi (2014), Chkili et al. (2014), Nomikos and Pouliasis (2011), Kang et al. (2009), Sadorsky (2006).
} 
MSCI World Energy Sector Index for oil-sensitive stocks, and the S\&P500 index to forecast monthly nominal and real crude oil prices - and to compare these forecasts against the no-change forecast (i.e. the random walk). The author uses various oil benchmarks (WTI, Brent and Dubai), as well as average world oil prices. The findings suggest that the US AMEX Oil Index and the MSCI World Energy Sector Index provide incremental forecasting ability for oil prices only in the short-run (i.e. 1 month ahead), as the no-change forecast is always superior for all forecasting horizons beyond 1 month.

The findings of Chen (2014) cannot be supported by Baumeister et al. (2015). In particular, these authors use a combination of low and high frequency data to forecast monthly real WTI crude oil prices. In particular, they use low frequency (monthly) oil prices and high frequency (daily) returns and the excess returns of oil company stocks (NYSE Oil Index). The authors compare the forecasting performance of these models based on stock market data against no-change forecasts, as well as those generated by models that use only oil market fundamentals. The authors find that the use of the returns and excess returns of the NYSE Oil Index offer marginally improved forecasts compared to the no-change forecast. Even more, they find that forecasts based on the NYSE Oil Index are not more accurate than forecasts based only on oil market fundamentals.

Furthermore, Yin and Yang (2016) use the dividend yield, dividend-price ratio and the earning-price ratio of the S\&P500 Index, as well as the book-to-market value ratio for the Dow Jones Industrial Average to predict WTI crude oil prices. They compare these forecasts against others generated by technical indicators for oil prices (i.e. moving averages, the momentum and on-balance volume averages). Their findings show that technical oil price strategies have superior predictive accuracy compared to forecasts based on stock market indicators.

Finally, Degiannakis and Filis (2017b) adopt a similar methodology with Baumeister et al. (2015) using (among others) daily returns and volatilities of major global stock markets to forecast monthly oil prices. In their study the authors compared these forecasts against no-change forecasts as well as state-of-the-art models. Contrary to the findings by Baumeister et al. (2015), Degiannakis and Filis (2017b) show that the use of high frequency stock market data (daily) provides incremental predictive accuracy to oil price forecasts, and incremental directional accuracy. 


\subsection{Oil price volatility forecasting}

In terms of oil price volatility forecasting, there are again only three studies that examine whether the information extracted from stock markets can provide incremental forecasting accuracy.

More specifically, Efimova and Serletis (2014) use daily S\&P500 returns to forecast the 1-day ahead WTI oil conditional volatility. The authors compare these forecasts against others generated by a random walk, past oil price volatility, oil price returns, natural gas price returns and electricity price returns. They report that univariate models based on the S\&P500 daily returns cannot produce better oil price volatility forecasts compared with those based on gas and electricity price returns.

In addition, Phan et al. (2016) assess whether volatilities of the E-mini S\&P500 index futures and the E-mini NASDAQ index futures can improve the forecasting accuracy of realized oil price volatility, compared to a model without any exogenous variables. Contrary to Efinova and Serletis, the authors show that crossmarket volatility interaction increases the forecasting accuracy of oil price volatility.

More recently, Degiannakis and Filis (2017a) show that the incorporation of stock market index volatility from the major global stock market indices (E-mini S\&P500, FTSE100, Eurostoxx 50 and Hang Seng) does improve the forecasting and directional accuracy of Brent crude oil volatility compared to a random walk, as well as to models based only on past information of Brent crude oil price volatility.

\subsection{Econometric methods and data used}

Interestingly enough, there is not a common model that is used in the aforementioned studies. For instance, in the oil price forecasting literature Chen (2014) and Yin and Yang (2016) use predictive regression models ${ }^{10}$, whereas Baumeister et al. (2015) and Degiannakis and Filis (2017b) employ a Mixed-Data Sampling (MIDAS) framework, which allows the researcher to combine low and high frequency data in the same model.

On the other hand, in the oil price volatility literature Efimova and Serletis (2014) use multivariable GARCH models (such as BEKK and DCC), whereas Phan et

\footnotetext{
${ }^{10}$ A standard predictive regression model takes the form $y_{t+h}=a+\boldsymbol{b} \boldsymbol{x}_{t}+u_{t+h}$, where $y_{t+h}$ denotes the oil price returns at time $t+h$ (h is the out-of-sample $h$-step-ahead forecasts) and $\boldsymbol{x}_{t}$ is the vector of exogenous variables.
} 
al. (2016) use an $\operatorname{EGARCH}(1,1)$ model with and without exogenous variables. By contrast, Degiannakis and Filis (2017a) employ a Heterogeneous Autoregressive (HAR) model with exogenous variables.

In terms of data, it is typical for authors to use WTI or Brent crude oil prices to measure oil price returns and volatility. Furthermore, the most common stock market data are from the US, including the S\&P500 index and NASDAQ, although the US oil sector index is also commonly used.

Finally, there is not much consistency in the measurement of oil price volatility given that authors use both conditional and realized oil price volatilities.

\section{Conclusions and ideas for further study}

The aim of this paper is to provide a detailed review of the literature on the relationship between oil and stock markets. We began with analysis of the transmission mechanisms between the two markets, and then proceeded to review literature on the effects of oil price fluctuations on stock market returns. Subsequently, we discussed the role of oil prices shocks on stock market performance and the interconnectedness between the volatilities of the two markets. Finally, we moved to analyze the informational content of stock markets for forecasting oil prices and oil price volatility.

The main conclusions that can be drawn are as follows. There are various channels that impact firm cash flow and/or their discount rates. These transmission channels suggest that higher oil prices lead to lower stock market returns-for stock markets operating in oil-importing economies. The reverse applies for oil-exporting countries. Further study in this area should concentrate on the possible asymmetric effects of positive and negative oil price changes. Additionally, theoretical transmission channels by which stock markets affect oil prices should be also developed.

Evidence mainly supports the theoretical premise that higher oil prices lead to lower stock market returns, yet only for the oil-importing countries, as the reverse hold true for oil-exporting countries. At a more detailed level, though, higher oil prices due to supply-side or precautionary demand shocks trigger negative responses from stock markets, whereas higher oil prices resulting from a boost in the global economy (aggregate demand shocks) are received as positive news by stock markets. More recent evidence shows that the relationship between the two markets is time- 
varying. Despite the above, the comprehensive study by Broadstock and Filis (2017) suggests that the importance of oil shocks to excess stock return is at the best marginal. Given this recent contradictory findings, there is scope to further expand this line of research by assessing the aforementioned effects (i) over the whole distribution of returns, (ii) as to whether they are direct or indirect and (iii) using firmlevel data from various countries.

Oil price volatility exercises a significant effect on stock market volatility, whereas the reverse holds true only in the case of the US market. Furthermore, additional evidence suggests that the volatility relationship is time-varying, which tends to intensify during the global financial crisis period. Interestingly, there are no studies that focus on firm-level data when considering volatility interconnectedness between the two markets, making this is an interesting avenue for further research.

Furthermore, despite the importance of oil prices for the global economy, the linkages between oil and stock markets (either in returns or in volatilities), as well as the fact that these markets exhibit a dynamic relationship, there is a small number of studies that have evaluated the information content of stock markets in forecasting both oil prices and oil price volatility. Thus, significant more research is required in this line of research, especially utilizing data of higher frequencies, which contain rich information on both the oil and stock markets. Another interesting avenue for further research is the production of density oil price and oil price volatility forecasts, based on information extracted from stock market fluctuations. Density forecasts are of particular importance for policy makers.

Even more, the in-depth review that is carried out in this paper provides information on the implications of these findings for portfolio holders. In short, there is some evidence to suggest that the oil market can provide hedging opportunities for stock markets. Nevertheless, more evidence needs to be accumulated on whether these findings hold at the firm-level, and whether the reverse hedging opportunities still apply (i.e. whether stock markets function as a hedging tool for oil price fluctuations). In addition, future studies should increase further in the applicability of the literature's results for investment purposes by focusing on optimal weight allocation for multi-asset portfolios, as well as, real financial assets such as index futures, ETFs of stock indices, etc.

We further show that the volatilities of the two markets are linked together in a dynamic fashion. Taking into consideration that there are assets, which mirror the 
performance of their volatilities (e.g. ETFs or futures contracts on implied volatility indices), research should examine the implications of this time-varying volatility interconnectedness for volatility investors.

Finally, given that the oil market has become more financialized in recent years due to the increased participation of hedge funds studies should investigate further the role of the speculative activity in the oil market and how this financialization has altered its nature.

\section{Acknowledgements}

Authors would like to thank Ian Mead, David Daniels, Melissa Lynes, Thomas Lee and James Smith for their constructive comments on a previous version of this study. The analysis and conclusions expressed here are those of the authors and not necessarily those of the U.S. Energy Information Administration.

\section{References}

Abel, A.B., \& Bernanke, B.S. (2001). Macroeconomics. Addison Wesley Longman Inc., New York.

Abhyankar, A., Xu, B., \& Wang, J. (2013). Oil price shocks and the stock market: evidence from Japan. Energy Journal, 34(2), 199-222.

Al Janabi, M. A. M., Hatemi-J, A. \& Irandoust, M. (2010). An Empirical Investigation of the Informational Efficiency of the GCC Equity Markets: Evidence from Bootstrap Simulation. International Review of Financial Analysis, 19(1), 47-54.

Alquist, R., \& Kilian, L. (2010). What do we learn from the price of crude oil futures? Journal of Applied Econometrics, 25(4), 539-573.

Angelidis, T., Degiannakis, S., \& Filis, G. (2015). US stock market regimes and oil price shocks. Global Finance Journal, 28, 132-146.

Antonakakis, N., Chatziantoniou, I., \& Filis, G. (2013). Dynamic co-movements of stock market returns, implied volatility and policy uncertainty. Economics Letters, 120(1), 87-92.

Antonakakis, N. \& Filis, G. (2013). Oil Prices and Stock Market Correlation: A TimeVarying Approach. International Journal of Energy and Statistics, 1(1), 1729.

Apergis, N., \& Miller, S. M. (2009). Do structural oil-market shocks affect stock prices? Energy Economics, 31(4), 569-575.

Arouri, M. E. H. (2011). Does crude oil move stock markets in Europe? A sector investigation. Economic Modelling, 28(4), 1716-1725.

Arouri, M E. H. (2012). Stock returns and oil price changes in Europe: A sector analysis. The Manchester School, 80(2), 237-261. 
Arouri, M. E. H., Jouini, J., \& Nguyen, D. K. (2011a). Volatility spillovers between oil prices and stock sector returns: implications for portfolio management. Journal of International Money and Finance, 30(7), 1387-1405.

Arouri, M. E. H., Jouini, J., \& Nguyen, D. K. (2012). On the impacts of oil price fluctuations on European equity markets: Volatility spillover and hedging effectiveness. Energy Economics, 34(2), 611-617.

Arouri, M. E. H., Lahiani, A., \& Nguyen, D. K. (2011b). Return and volatility transmission between world oil prices and stock markets of the GCC countries. Economic Modelling, 28(4), 1815-1825.

Arouri, M. E. H., \& Nguyen, D. K. (2010). Oil prices, stock markets and portfolio investment: evidence from sector analysis in Europe over the last decade. Energy Policy, 38(8), 4528-4539.

Arouri, M. E. H., \& Rault, C. (2012). Oil prices and stock markets in GCC countries: empirical evidence from panel analysis. International Journal of Finance \& Economics, 17(3), 242-253.

Asteriou, D., \& Bashmakova, Y. (2013). Assessing the impact of oil returns on emerging stock markets: A panel data approach for ten Central and Eastern European Countries. Energy Economics, 38, 204-211.

Awartani, B., \& Maghyereh, A. I. (2013). Dynamic spillovers between oil and stock markets in the Gulf Cooperation Council Countries. Energy Economics, 36, $28-42$.

Ayadi, O. F. (2005). Oil price fluctuations and the Nigerian economy. OPEC review, 29(3), 199-217.

Baba, Y., Engle, R. F., Kraft, D. F., \& Kroner, K. F. (1991). Multivariate simultaneous generalized $\mathrm{ARCH}$, Unpublished manuscript, Department of Economics, University of California, San Diego. San Diego.

Bachmeier, L. (2008). Monetary policy and the transmission of oil shocks. Journal of Macroeconomics, 30(4), 1738-1755.

Barro, R.J. (1984). Macroeconomics. Wiley, New York.

Barsky, R.B., and L. Kilian, (2002). Do We Really Know that Oil Caused the Great Stagflation? A Monetary Alternative. NBER Chapters, 137-198.

Barsky, R.B., and L. Kilian, (2004). Oil and the Macroeconomy since the 1970s. Journal of Economic Perspectives, 18(4), 115-134.

Bashar, A.Z. (2006). Wild oil prices, but brave stock markets! The case of GCC stock markets. Operational Research, 6(2), 145-162.

Basher, S. A., Haug, A. A., \& Sadorsky, P. (2012). Oil prices, exchange rates and emerging stock markets. Energy Economics, 34(1), 227-240.

Basher, S. A., \& Sadorsky, P. (2006). Oil price risk and emerging stock markets. Global Finance Journal, 17(2), 224-251.

Baumeister, C., Guérin, P., \& Kilian, L. (2015). Do high-frequency financial data help forecast oil prices? The MIDAS touch at work. International Journal of Forecasting, 31(2), 238-252.

Baumeister, C., \& Kilian, L. (2012). Real-time forecasts of the real price of oil. Journal of Business \& Economic Statistics, 30(2), 326-336. 
Baumeister, C., \& Kilian, L. (2015). Forecasting the real price of oil in a changing world: a forecast combination approach. Journal of Business \& Economic Statistics, 33(3), 338-35.

Baumeister, C., Kilian, L., \& Lee, T. K. (2014). Are there gains from pooling realtime oil price forecasts? Energy Economics, 46, S33-S43.

Baumeister, C., \& Kilian, L. (2014). What central bankers need to know about forecasting oil prices. International Economic Review, 55(3), 869-889.

Baumeister, C., \& Peersman, G. (2013). Time-varying effects of oil supply shocks on the US economy. American Economic Journal: Macroeconomics, 5(4), 1-28.

Bernanke, B. S. (1983). Non-monetary effects of the financial crisis in the propagation of the Great Depression. National Bureau of Economic Research, working paper series.

Bernanke, B. S. (2006). Energy and the Economy. Speech to the Economic Club of Chicago, June, 15.

Bharn, R., \& Nikolova, B. (2010). Global oil prices, oil industry and equity returns: Russian experience. Scottish Journal of Political Economy, 57(2), 169-186.

Bjornland, C.H. (2009). Oil price shocks and stock market booms in an oil exporting country. Scottish Journal of Political Economy, 2(5), 232-254.

Bohi, D. R. (1991). On the macroeconomic effects of energy price shocks. Resources and Energy, 13(2), 145-162.

Boldanov, R., Degiannakis, S., \& Filis, G. (2016). Time-varying correlation between oil and stock market volatilities: Evidence from oil-importing and oilexporting countries. International Review of Financial Analysis, 48, 209-220.

Bouri, E. (2015). Oil volatility shocks and the stock markets of oil-importing MENA economies: A tale from the financial crisis. Energy Economics, 51, 590-598.

Boyer, M.M. \& Filion, D. (2007). Common and fundamental factors in stock returns of Canadian oil and gas companies. Energy Economics, 29, 428-53.

Broadstock, D.C., Cao, H. and Zhang, D. (2012). Oil shocks and their impact on energy related stocks in China. Energy Economics, 34, 1888-1895.

Broadstock, D. C., \& Filis, G. (2014). Oil price shocks and stock market returns: New evidence from the United States and China. Journal of International Financial Markets, Institutions and Money, 33, 417-433.

Broadstock, D. C., \& Filis, G. (2017). Time-varying probabilities of the importance of oil shocks to US stock returns.

Broadstock, D. C., Wang, R., \& Zhang, D. (2014). Direct and indirect oil shocks and their impacts upon energy related stocks. Economic Systems, 38(3), 451-467.

Brown, S.J., \& Otsuki, T. (1990). Macroeconomic Factors and the Japanese Equity Markets: The CAPMD project, in E. J. Elton and M. Gruber (eds.), Japanese Capital Markets, New York: Harper \& Row.

Brown, S. P., \& Yucel, M. K. (1999). Oil prices and US aggregate economic activity: a question of neutrality. Economic \& Financial Review, 16.

Brown, S. P., \& Yücel, M. K. (2002). Energy prices and aggregate economic activity: an interpretative survey. The Quarterly Review of Economics and Finance, 42(2), 193-208. 
Buyuksahin, B., \& Robe, M. A. (2014). Speculators, commodities and cross-market linkages. Journal of International Money and Finance, 42, 38-70.

Chang, C. L., McAleer, M., \& Tansuchat, R. (2013). Conditional correlations and volatility spillovers between crude oil and stock index returns. The North American Journal of Economics and Finance, 25, 116-138.

Chen, S.S. (2010). Do higher oil prices push the stock market into bear territory? Energy Economics, 32(2), 490-495.

Chen, S. S. (2014). Forecasting Crude Oil Price Movements with Oil-Sensitive Stocks. Economic Inquiry, 52(2), 830-844.

Chen, N.F., Roll, R., \& Ross, S.A. (1986). Economic forces and the stock market. Journal of Business, 59, 383-403.

Chkili, W., Hammoudeh, S., \& Nguyen, D. K. (2014). Volatility forecasting and risk management for commodity markets in the presence of asymmetry and long memory. Energy Economics, 41, 1-18.

Choi, K. \& Hammoudeh, S. (2010). Volatility Behavior of Oil, Industrial Commodity and Stock Markets in a Regime-Switching Environment. Energy Policy, 38(8), 4388-4399.

Chuku, C., Effiong, E., \& Sam, N. (2010). Oil price distortions and their short-and long-run impacts on the Nigerian economy. Paper presented at the $51^{\text {st }}$ annual conference of the Nigerian Economic Society (NES) held in Abuja, between $25^{\text {th }}-27^{\text {th }}$ October.

Ciner, C. (2013). Oil and stock returns: Frequency domain evidence. Journal of International Financial Markets, Institutions and Money 23, 1-11.

Cong, R.G., Wei, Y.M., Jiao, J.L., \& Fan, Y. (2008). Relationships between oil price shocks and stock market: An empirical analysis from China. Energy Policy, 36, 3544-3553.

Coppola, A. (2008). Forecasting oil price movements: Exploiting the information in the futures market. Journal of Futures Markets, 28(1), 34-56.

Cunado, J., \& De Gracia, F. P. (2005). Oil prices, economic activity and inflation: evidence for some Asian countries. The Quarterly Review of Economics and Finance, 45(1), 65-83.

Degiannakis, S., \& Filis, G. (2017a). Forecasting oil price realized volatility using information channels from other asset classes, Journal of International Money and Finance, 76, 28-49.

Degiannakis, S., \& Filis, G. (2017b). Forecasting oil prices. https://mpra.ub.unimuenchen.de/77531/1/MPRA_paper_77531.pdf

Degiannakis, S., Filis, G., \& Kizys, R. (2014). The effects of oil price shocks on stock market volatility: evidence from European data. The Energy Journal, 35(1), 3556.

Degiannakis, S., Filis, G., \& Floros, C. (2013). Oil and stock returns: Evidence from European industrial sector indices in a time-varying environment. Journal of International Financial Markets, Institutions and Money, 26, 175-191. 
Diebold, F. X., \& Y1lmaz, K. (2012). Better to give than to receive: predictive directional measurement of volatility spillovers. International Journal of Forecasting, 28, 57-66.

Diebold, F. X., \& Y1lmaz, K. (2014). On the network topology of variance decompositions: Measuring the connectedness of financial firms. Journal of Econometrics, 182(1), 119-134.

Dohner, R. S. (1981). Energy prices, economic activity and inflation: survey of issues and results. Energy prices, inflation and economic activity. Ballinger, Cambridge, $M A$.

Driesprong, G., Jacobsen, B., \& Maat, B. (2008). Striking oil: Another puzzle? Journal of Financial Economics, 89(2), 307-327.

Du, L., \& He, Y. (2015). Extreme risk spillovers between crude oil and stock markets. Energy Economics, 51, 455-465.

Edelstein, P., \& Kilian, L. (2009). How sensitive are consumer expenditures to retail energy prices? Journal of Monetary Economics, 56(6), 766-779.

Efimova, O., \& Serletis, A. (2014). Energy markets volatility modelling using GARCH. Energy Economics, 43, 264-273.

El-Sharif, I., Brown, D., Burton, B., Nixon, B. \& Russell, A. (2005). Evidence on the nature and extent of the relationship between oil prices and equity values in UK. Energy Economics, 27, 819-30.

Elyasiani, E., Mansur, I., \& Odusami, B. (2011). Oil price shocks and industry stock returns. Energy Economics, 33(5), 966-974.

Emami, K., \& Adibpour, M. (2012). Oil income shocks and economic growth in Iran. Economic Modelling, 29(5), 1774-1779.

Engle, R.F., \& Kroner, K.F. (1995). Multivariate simultaneous generalized ARCH. Economic Theory, 11, 122-150.

Engle, R. F., \& Kroner, K. F. (1995). Multivariate simultaneous generalized ARCH. Econometric theory, 11(01), 122-150.

Engle, F.R. (2002). Dynamic conditional correlation: A simple class of multivariate GARCH models. Journal of Business and Economic Statistics, 20, 339-350.

Ewing, B. T., \& Malik, F. (2016). Volatility spillovers between oil prices and the stock market under structural breaks. Global Finance Journal, 29, 12-23.

Faff, R. W., \& Brailsford, T. J. (1999). Oil price risk and the Australian stock market. Journal of Energy Finance \& Development, 4(1), 69-87.

Fama, E. F., \& French, K. R. (1993). Common risk factors in the returns on stocks and bonds. Journal of Financial Economics, 33(1), 3-56.

Fang, C. R., \& You, S. Y. (2014). The impact of oil price shocks on the large emerging countries' stock prices: Evidence from China, India and Russia. International Review of Economics \& Finance, 29, 330-338.

Farzanegan, M. R. (2011). Oil revenue shocks and government spending behavior in Iran. Energy Economics, 33(6), 1055-1069.

Fattouh, B., Kilian, L., \& Mahadeva, L. (2013). The Role of Speculation in Oil Markets: What Have We Learned So Far? The Energy Journal, 34(3). 
Ferson, W. E., \& Harvey, C. R. (1995). Predictability and time-varying risk in world equity markets. Research in Finance, 13, 25-88.

Filis, G. (2010). Macro economy, stock market and oil prices: Do meaningful relationships exist among their cyclical fluctuations? Energy Economics, 32(4), 877-886.

Filis, G., Degiannakis, S. \& Floros, C. (2011). Dynamic correlation between stock market and oil prices: The case of oil-importing and oil-exporting countries. International Review of Financial Analysis, 20(3), 152-164.

Filis, G., \& Chatziantoniou, I. (2014). Financial and monetary policy responses to oil price shocks: evidence from oil-importing and oil-exporting countries. Review of Quantitative Finance and Accounting, 42(4), 709-729.

Financial Times (2006). Oil slide spurs global equity rally, by Tony Tassell. October, 13th. https://www.ft.com/content/1ef0a778-5a17-11db-8f16-0000779e2340.

Gupta, R., \& Modise, M. P. (2013). Does the source of oil price shocks matter for South African stock returns? A structural VAR approach. Energy Economics, $40,825-831$.

Hamao, Y. (1988). An empirical examination of arbitrage pricing theory: Using Japanese data, Japan and the World Economy, 1, 45-61

Hamilton, D.J. (1983). Oil and the macroeconomy since World War II. The Journal of Political Economy, 9, 228-248.

Hamilton, J. D. (1988). Are the macroeconomic effects of oil-price changes symmetric? A comment. In Carnegie-Rochester Conference Series on Public Policy (Vol. 28, pp. 369-378). North-Holland.

Hamilton, D.J. (1996). This is what happened to the oil price-macroeconomy relationship. Journal of Monetary Economics, 38, 215-220.

Hamilton, J. D. (2003). What is an oil shock? Journal of Econometrics, 113(2), 363398.

Hamilton, J. D. (2009a). Understanding Crude Oil Prices. The Energy Journal, 30(2), 179-206.

Hamilton, J. D. (2009b). Causes and Consequences of the Oil Shock of 2007-08. Brookings Papers on Economic Activity, 215.

Hammoudeh, S., \& Aleisa, E. (2004). Dynamic relationship among GCC stock markets and NYMEX oil futures. Contemporary Economic Policy, 22, 250269.

Hammoudeh, S., \& Li, H. (2005). Oil sensitivity and systematic risk in oil-sensitive stock indices. Journal of Economics and Business, 57(1), 1-21.

Hammoudeh, S., Dibooglu, S., \& Aleisa, E. (2004). Relationships among US oil prices and oil industry equity indices. International Review of Economics \& Finance, 13(4), 427-453.

Hampton, M. (1995). Options. In: Jameson, R. (Ed.), Managing Energy Price Risk. London, 97-116.

Henriques, I., \& Sadorsky, P. (2008). Oil prices and the stock prices of alternative energy companies. Energy Economics, 30(3), 998-1010. 
Herrera, A. M., Lagalo, L. G., \& Wada, T. (2015). Asymmetries in the response of economic activity to oil price increases and decreases? Journal of International Money and Finance, 50, 108-133.

Huang, D.R., Masulis, R.W. and Stoll, H. (1996). Energy shocks and financial markets. Journal of Futures Markets, 16(1), 1-27.

Jammazi, R., \& Aloui, C. (2010). Wavelet decomposition and regime shifts: Assessing the effects of crude oil shocks on stock market returns. Energy Policy, 38(3), 1415-1435.

Jiménez-Rodríguez, R. (2015). Oil price shocks and stock markets: testing for nonlinearity. Empirical Economics, 48(3), 1079-1102.

Jiménez-Rodríguez, R., \& Sánchez, M. (2005). Oil price shocks and real GDP growth: empirical evidence for some OECD countries. Applied economics, 37(2), 201-228.

Jones, C.M., Kaul, G. (1996). Oil and stock markets. Journal of Finance, 51, 463-491.

Jung, H., \& Park, C. (2011). Stock market reaction to oil price shocks. Journal of Economic Theory and Econometrics, 22, 1-29.

Kaneko, T., \& Lee, B. S. (1995). Relative importance of economic factors in the US and Japanese stock markets. Journal of the Japanese and International Economies, 9(3), 290-307.

Kang, S. H., Kang, S. M., \& Yoon, S. M. (2009). Forecasting volatility of crude oil markets. Energy Economics, 31(1), 119-125.

Kang, W., de Gracia, F. P., \& Ratti, R. A. (2017). Oil price shocks, policy uncertainty, and stock returns of oil and gas corporations. Journal of International Money and Finance, 70, 344-359.

Kang, W., \& Ratti, R. A. (2013). Oil shocks, policy uncertainty and stock market return. Journal of International Financial Markets, Institutions and Money, 26, 305-318.

Kang, W., Ratti, R. A., \& Yoon, K. H. (2015a). The impact of oil price shocks on the stock market return and volatility relationship. Journal of International Financial Markets, Institutions and Money, 34, 41-54.

Kang, W., Ratti, R. A., \& Yoon, K. H. (2015b). Time-varying effect of oil market shocks on the stock market. Journal of Banking \& Finance, 61, S150-S163.

Khalfaoui, R., Boutahar, M., \& Boubaker, H. (2015). Analyzing volatility spillovers and hedging between oil and stock markets: Evidence from wavelet analysis. Energy Economics, 49, 540-549.

Kilian, L. (2008a). Exogenous oil supply shocks: how big are they and how much do they matter for the US economy? The Review of Economics and Statistics, 90(2), 216-240.

Kilian, L. (2008b). The economic effects of energy price shocks. Journal of Economic Literature, 46(4), 871-909.

Kilian, L. (2009). Not All Oil Price Shocks Are Alike: Disentangling Demand and Supply Shocks in the Crude Oil Market. American Economic Review, 99(3), 1053-69. 
Kilian, L., \& Park, C. (2009). The impact of oil price shocks on the US stock market. International Economic Review, 50(4), 1267-1287.

Kilian, L., \& Vigfusson, R. J. (2011). Are the responses of the US economy asymmetric in energy price increases and decreases? Quantitative Economics, 2(3), 419-453.

Knetsch, T. A. (2007). Forecasting the price of crude oil via convenience yield predictions. Journal of Forecasting, 26(7), 527-549.

Korhonen, I., \& Ledyaeva, S. (2010). Trade linkages and macroeconomic effects of the price of oil. Energy Economics, 32(4), 848-856.

Laopodis, N. T. (2011). Equity prices and macroeconomic fundamentals: International evidence. Journal of International Financial Markets, Institutions and Money, 21(2), 247-276.

Lee, Y. H., \& Chiou, J. S. (2011). Oil sensitivity and its asymmetric impact on the stock market. Energy, 36(1), 168-174.

Lee, K., Ni, S., \& Ratti, R. A. (1995). Oil shocks and the macroeconomy: the role of price variability. The Energy Journal, 39-56.

Lescaroux, F., \& Mignon, V. (2008). On the influence of oil prices on economic activity and other macroeconomic and financial variables. OPEC Energy Review, 32(4), 343-380.

Manescu, C., \& Van Robays, I. (2014). Forecasting the Brent oil price: addressing time-variation in forecast performance. ECB Working paper series No 1735.

Maghyereh, A. I., Awartani, B., \& Bouri, E. (2016). The directional volatility connectedness between crude oil and equity markets: New evidence from implied volatility indexes. Energy Economics, 57, 78-93.

Malik, F., \& Ewing, B. T. (2009). Volatility transmission between oil prices and equity sector returns. International Review of Financial Analysis, 18(3), 95100.

Malik, F., \& Hammoudeh, S. (2007). Shock and volatility transmission in the oil, US and Gulf equity markets. International Review of Economics \& Finance, 16(3), 357-368.

Mendoza, O., \& Vera, D. (2010). The asymmetric effects of oil shocks on an oilexporting economy. Cuadernos de Economía, 47(135), 3-13.

Mensi, W., Beljid, M., Boubaker, A., \& Managi, S. (2013). Correlations and volatility spillovers across commodity and stock markets: Linking energies, food, and gold. Economic Modelling, 32, 15-22.

Miller, J.I., \& Ratti, R.A. (2009). Crude oil and stock markets: Stability, instability, and bubbles. Energy Economics, 31(4), 559-568.

Mohanty, S. K., \& Nandha, M. (2011). Oil risk exposure: the case of the US oil and gas sector. Financial review, 46(1), 165-191.

Mohanty, S. K., Nandha, M., Turkistani, A. Q. \& Alaitani, M. Y. (2011). Oil Price Movements and Stock Market Returns: Evidence from Gulf Cooperation Council (GCC) countries. Global Finance Journal, 22(1), 42-55. 
Mohanty, S. K., Akhigbe, A., Al-Khyal, T. A., \& Bugshan, T. (2013). Oil and stock market activity when prices go up and down: the case of the oil and gas industry. Review of Quantitative Finance and Accounting, 41(2), 253-272.

Mork, K. A., Olsen, Ø. \& Mysen, H. T. (1994). Macroeconomic responses to oil price increases and decreases in seven OECD countries. The Energy Journal, 19-35.

Murat, A., \& Tokat, E. (2009). Forecasting oil price movements with crack spread futures. Energy Economics, 31(1), 85-90.

Nandha, M., \& Brooks, R. (2009). Oil prices and transport sector returns: an international analysis. Review of Quantitative Finance and Accounting, 33(4), 393-409.

Nandha, M., \& Faff, R. (2008). Does oil move equity prices? A global view. Energy Economics, 30, 986-997.

Narayan, P. K., \& Gupta, R. (2015). Has oil price predicted stock returns for over a century? Energy Economics, 48, 18-23.

Narayan, P.K., Sharma, S.S., 2011. New evidence on oil price and firm returns. Journal of Banking and Finance, 35(12), 3253-3262.

Nomikos, N. K., \& Pouliasis, P. K. (2011). Forecasting petroleum futures markets volatility: The role of regimes and market conditions. Energy Economics, 33(2), 321-337.

Oberndorfer, U. (2009). Energy prices, volatility, and the stock market: Evidence from the Eurozone. Energy Policy, 37(12), 5787-5795.

O'Neill, J.T., Penm, J., \& Terrell, D.R. (2008). The role of higher oil prices: A case of major developed countries. Research in Finance, 24, 287-299.

Papapetrou, E. (2001). Oil price shocks, stock market, economic activity and employment in Greece. Energy Economics, 23(5), 511-532.

Park, J., \& Ratti, R.A. (2008). Oil prices and stock markets in the U.S. and 13 European countries. Energy Economics, 30, 2587-2608.

Phan, D. H. B., Sharma, S. S., \& Narayan, P. K. (2015). Oil price and stock returns of consumers and producers of crude oil. Journal of International Financial Markets, Institutions and Money, 34, 245-262.

Phan, D. H. B., Sharma, S. S., \& Narayan, P. K. (2016). Intraday volatility interaction between the crude oil and equity markets. Journal of International Financial Markets, Institutions and Money, 40, 1-13.

Pindyck, R. S., 2003. Volatility in natural gas and oil markets. Massachusetts Institute of Technology working paper.

Primiceri, G. E. (2005). Time varying structural vector autoregressions and monetary policy. The Review of Economic Studies, 72(3), 821-852.

Prokopczuk, M., Symeonidis, L., \& Wese Simen, C. (2015). Do Jumps Matter for Volatility Forecasting? Evidence from Energy Markets. Journal of Futures Markets, 1-35.

Ramos, S. B., \& Veiga, H. (2011). Risk factors in oil and gas industry returns: International evidence. Energy Economics, 33(3), 525-542. 
Reuters (2016). Oil rally propels Wall Street to record, by Chuck Mikolajczak. November, 18th. http://www.reuters.com/article/us-global-marketsidUSKBN13G01L.

Ross, S. (1989). Information and volatility: the no-arbitrage Martingale approach to timing and resolution irrelevancy. Journal of Finance, 44(1), 1-17.

Sadorsky, P. (1999). Oil price shocks and stock market activity. Energy Economics, 21, 449-469.

Sadorsky, P. (2001). Risk factors in stock returns of Canadian oil and gas companies. Energy Economics, 23, 17-28.

Sadorsky, P. (2006). Modeling and forecasting petroleum futures volatility. Energy Economics, 28, 467-488.

Sadorsky, P. (2008). Assessing the impact of oil prices on firms of different sizes: Its tough being in the middle. Energy Policy, 36(10), 3854-3861.

Sadorsky, P. (2012). Correlations and Volatility Spillovers between Oil Prices and the Stock Prices of Clean Energy and Technology Companies. Energy Economics, 34(1), 248-255.

Scholtens, B., \& Yurtsever, C. (2012). Oil price shocks and European industries. Energy Economics, 34(4), 1187-1195.

Sévi, B. (2014). Forecasting the volatility of crude oil futures using intraday data. European Journal of Operational Research, 235(3), 643-659.

Silvennoinen, A., \& Thorp, S. (2013). Financialization, crisis and commodity correlation dynamics. Journal of International Financial Markets, Institutions and Money, 24, 42-65.

Svensson, L. E. (2005). Oil prices and ECB monetary policy. Briefing Paper for the Committee on Economic and Monetary Affairs of the European Parliament.

Svensson, L. E. (2006). Monetary-policy challenges: monetary-policy responses to oil-price changes. In Prepared for the Bellagio Group Meeting at the Federal Reserve Board.

Tang, W., Wu, L., \& Zhang, Z. (2010). Oil price shocks and their short-and long-term effects on the Chinese economy. Energy Economics, 32, S3-S14.

Taylor, J. B. (1993, December). Discretion versus policy rules in practice. In Carnegie-Rochester conference series on public policy (Vol. 39, pp. 195-214). North-Holland.

Tsai, C. L. (2015). How do US stock returns respond differently to oil price shocks pre-crisis, within the financial crisis, and post-crisis? Energy Economics, 50, 47-62.

The Conversation (2013). How the Syrian unrest affect world markets, by George Filis. August, 29th. https://www.ft.com/content/1ef0a778-5a17-11db-8f16$0000779 \mathrm{e} 2340$.

Vo, M. (2011). Oil and stock market volatility: A multivariate stochastic volatility perspective. Energy Economics, 33(5), 956-965.

Wall Street Journal (2016). Oil, stocks at tightest correlation in 26 years, by Tommy Stubbington and Georgi Kantchev. January, 25th. 
https://www.wsj.com/articles/oil-stocks-dance-the-bear-market-tango1453722783.

Wang, Y., Wu, C., \& Yang, L. (2013). Oil price shocks and stock market activities: Evidence from oil-importing and oil-exporting countries. Journal of Comparative Economics, 41(4), 1220-1239.

Yin, L., \& Yang, Q. (2016). Predicting the oil prices: Do technical indicators help? Energy Economics, 56, 338-350.

Zagaglia, P. (2010). Macroeconomic factors and oil futures prices: a data-rich model. Energy Economics, 32(2), 409-417. 
Figures

Figure 1: Dow Jones Industrial Average and WTI Crude oil prices

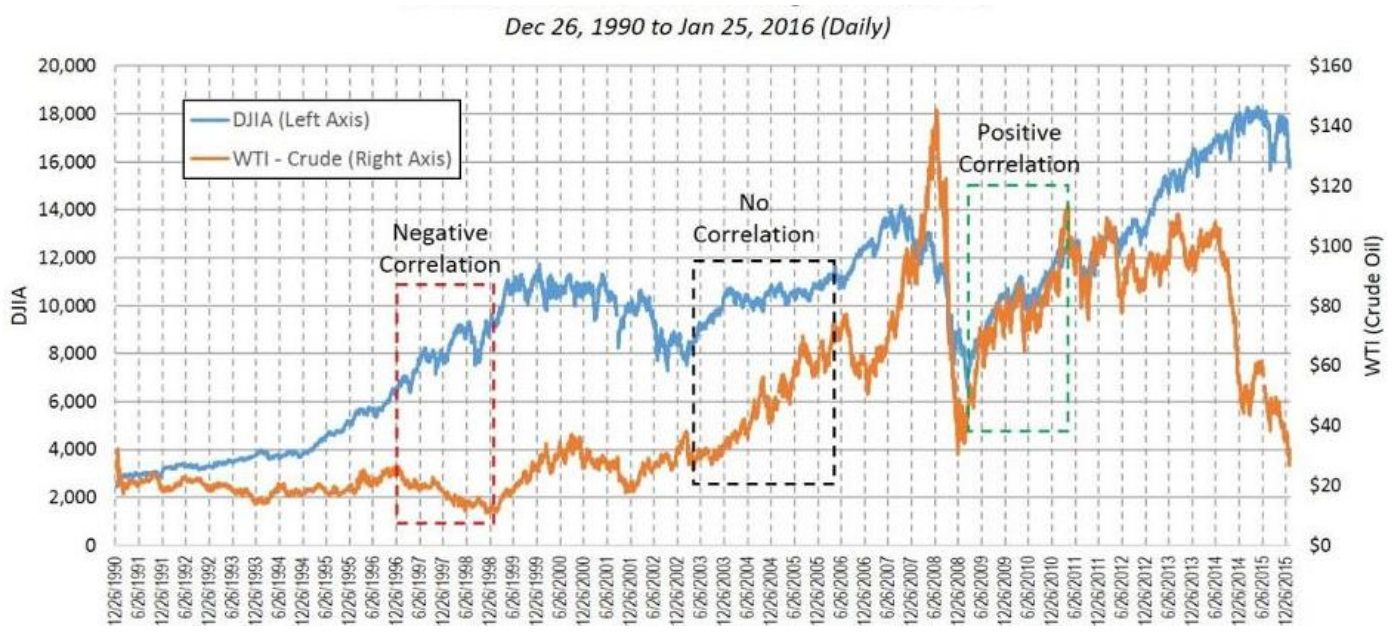

Source: Forbes, 2016.

Figure 2: The effects of an oil price increase on an oil-importing country.
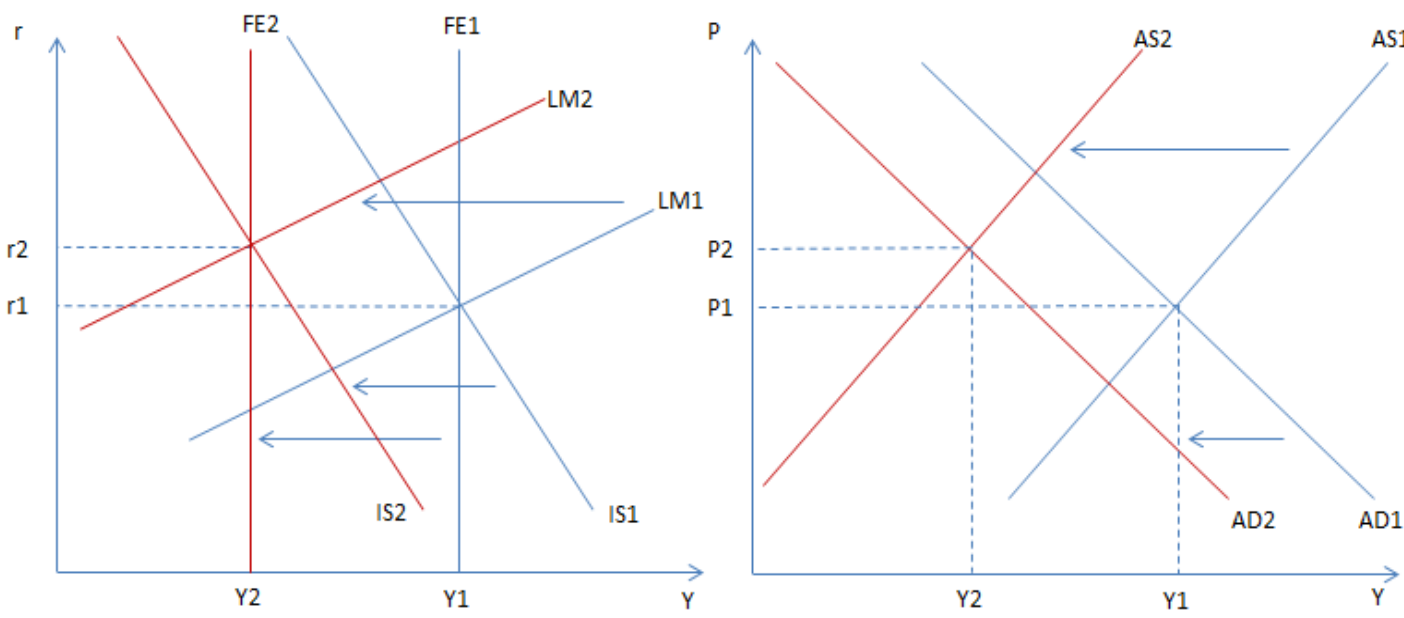

Adapted from Filis and Chatziantoniou (2014). Y1, P1, AD1, AS1, FE1, LM1, IS1, r1 refer to aggregate output, price levels, aggregate demand, aggregate supply, labour market, money market equilibrium, goods market equilibrium and interest rates, respectively, before the oil price increase. Y2, P2, AD2, AS2, FE2, LM2, IS2, r2 refer to aggregate output, price levels, aggregate demand, aggregate supply, labour market, money market equilibrium, good market equilibrium, and interest rates, respectively, after the oil price increase. 
Figure 3: The effects of an oil price increase on an oil-exporting country.
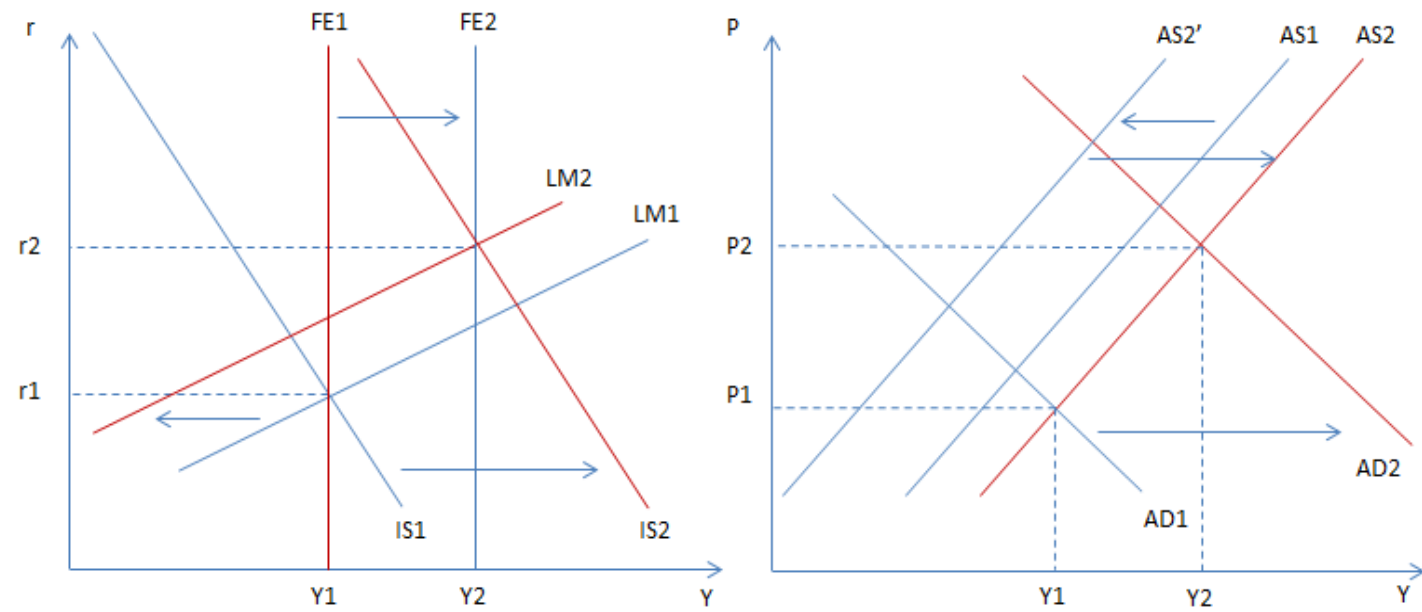

Adapted from Filis and Chatziantoniou (2014). Y1, P1, AD1, AS1, FE1, LM1, IS1, r1 refer to aggregate output, price levels, aggregate demand, aggregate supply, labour market, money market equilibrium, goods market equilibrium and interest rates, respectively, before the oil price increase. Y2, $\mathrm{P} 2, \mathrm{AD} 2, \mathrm{AS} 2, \mathrm{FE} 2, \mathrm{LM} 2, \mathrm{IS} 2, \mathrm{r} 2$ refer to aggregate output, price levels, aggregate demand, aggregate supply, labour market, money market equilibrium, good market equilibrium, and interest rates, respectively, after the oil price increase.

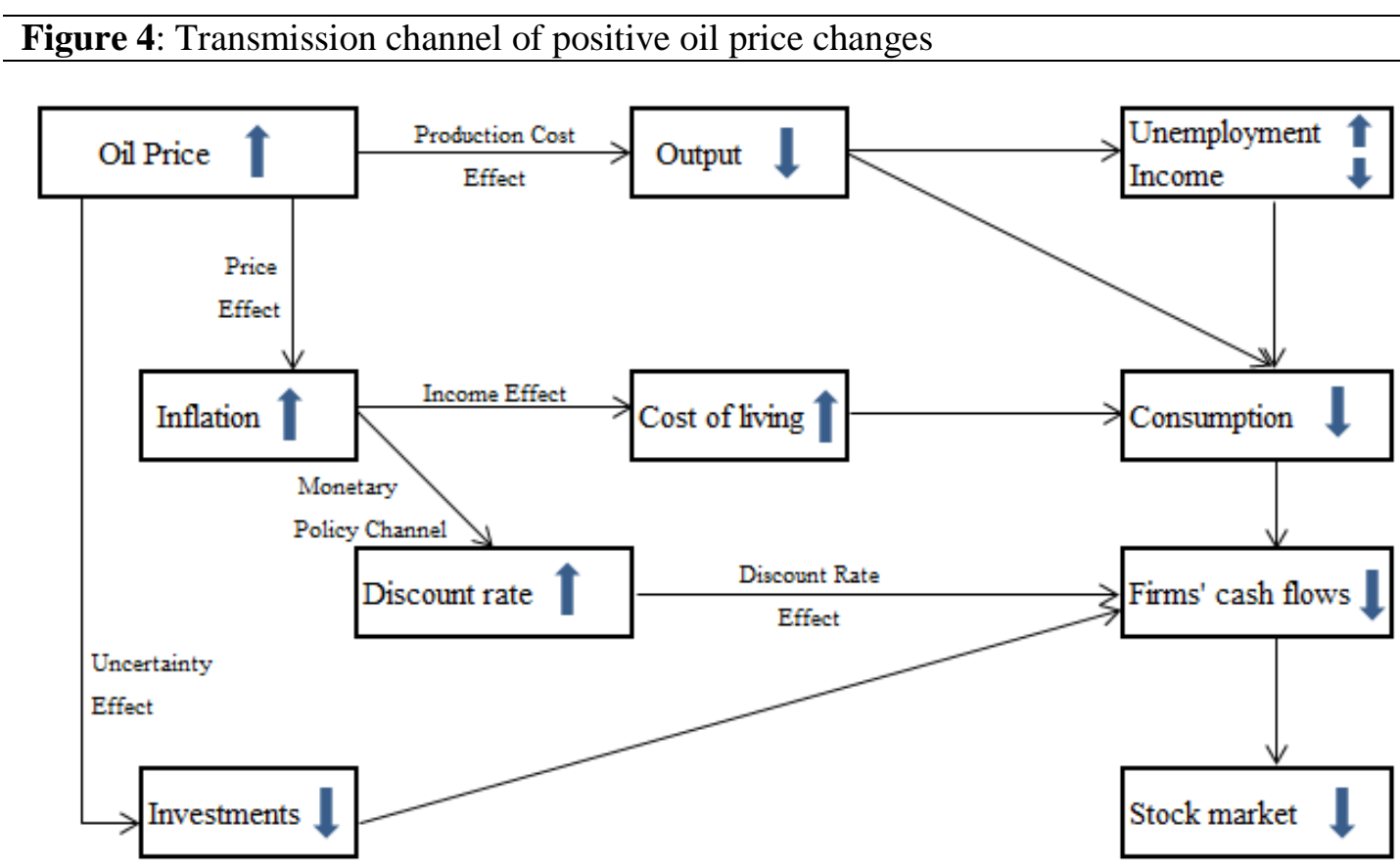

Adapted from Tang et al. (2010). 